Supporting Information

\title{
Confinement of Water-Soluble Cationic Substrates in a Cationic Molecular Cage by Capping the Portals with Tripodal Anions
}

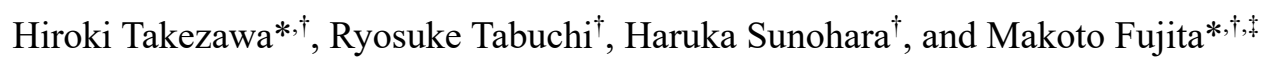

'Department of Applied Chemistry, School of Engineering, The University of Tokyo, 7-3-1 Hongo, Bunkyo-ku, Tokyo 113-8656, Japan. "Division of Advanced Molecular Science, Institute for Molecular Science (IMS), 5-1 Higashiyama, Myodaiji, Okazaki, Aichi 444-8787, Japan.

E-mail: takezawa@appchem.t.u-tokyo.ac.jp,mfujita@appchem.t.u-tokyo.ac.jp

1. Materials and instrumentations

2. Addition of tripodal anion 2 to cage 1

3. X-ray crystallographic analyses of $1 \cdot 2$

4. Inclusion of cationic guest 3 in cage 1 with the help of anion 2

5. X-ray crystallographic analyses of $1 \cdot(2 \cdot 3)_{4}$

6. Inclusion of cationic substrates $4 a-c$ in cage 1 with the help of anion 2

7. Manipulative guest exchange by attaching of tripodal anion 2 


\section{Materials and instrumentations}

${ }^{1} \mathrm{H}$ and ${ }^{13} \mathrm{C}$ NMR spectra were recorded on a Bruker AVANCE $500 \mathrm{MHz}$ spectrometer equipped with a CP-TCI cryoprobe or a Bruker AVANCE III HD $500 \mathrm{MHz}$ spectrometer equipped with a PABBO probe (500 MHz for ${ }^{1} \mathrm{H}$ NMR and $125 \mathrm{MHz}$ for $\left.{ }^{13} \mathrm{C} \mathrm{NMR}\right)$ at $300 \mathrm{~K}$ unless otherwise stated. TMS ( $\mathrm{CDCl}_{3}$ solution) in a capillary served as an internal standard ( $\delta=0 \mathrm{ppm}$ for ${ }^{1} \mathrm{H}$ and ${ }^{13} \mathrm{C}$ NMR) for $\mathrm{D}_{2} \mathrm{O}$ solutions. Solvents and reagents were purchased from TCI Co., Ltd., FUJIFILM Wako Pure Chemical Corp., Sigma-Aldrich Co., and Kanto Chemical Co., Inc. and used without further purification. Coordination cage $\mathbf{1}^{1}$ and Sodium 1,3,5benzenetrimethanesulfonate $(2)^{2}$ were prepared according to the established methods.

Single crystal X-ray diffraction data were collected on a BRUKER APEX-II CCD rotating anode diffractometer equipped with focusing mirrors with $\operatorname{Mo} K \alpha(\lambda=0.71073 \AA)$ radiation under cryogenic conditions, which are controlled with a cryostat system equipped with a $\mathrm{N}_{2}$ generator (Japan Thermal Eng. Co., Ltd.). Bruker APEX2 software was used for the data collections and the data processing. The structures were solved by SHELXS-97 package using direct methods and refined by full-matrix least-squares methods using SHELXL2017/1 embedded in ShelXle suits. ${ }^{3,4}$ All C-H and N-H hydrogen positions were calculated and refined using a riding atom model after the refinement of the non-hydrogen atoms. In all structures, the framework atoms of 1 were firstly located and refined and then the atoms of anion $\mathbf{2}$, guests and other counter anions were located and refined. The large Q-peaks isolated from other atoms were assigned as water oxygen atoms and refined. Careful refinements with minimal restraints around the disordered parts of anion $\mathbf{2}$ and capping ligands of $\mathbf{1}$ clearly revealed the multiple interactions between cage $\mathbf{1}$, anion $\mathbf{2}$ and $\mathbf{3}$. For the structure of $\mathbf{1 \cdot 2}$, the SQUEEZE program in PLATON ${ }^{5}$ was used for the analysis to remove the disordered unassignable solvent densities in the void. Although several alerts A and B are raised in the CheckCIF, these alerts are caused by the disordered water molecules in the crystal and therefore do not raise serious concerns for the discussions. The responses for these alerts have been described in the CIF files. 


\section{Addition of tripodal anion 2 to cage 1}
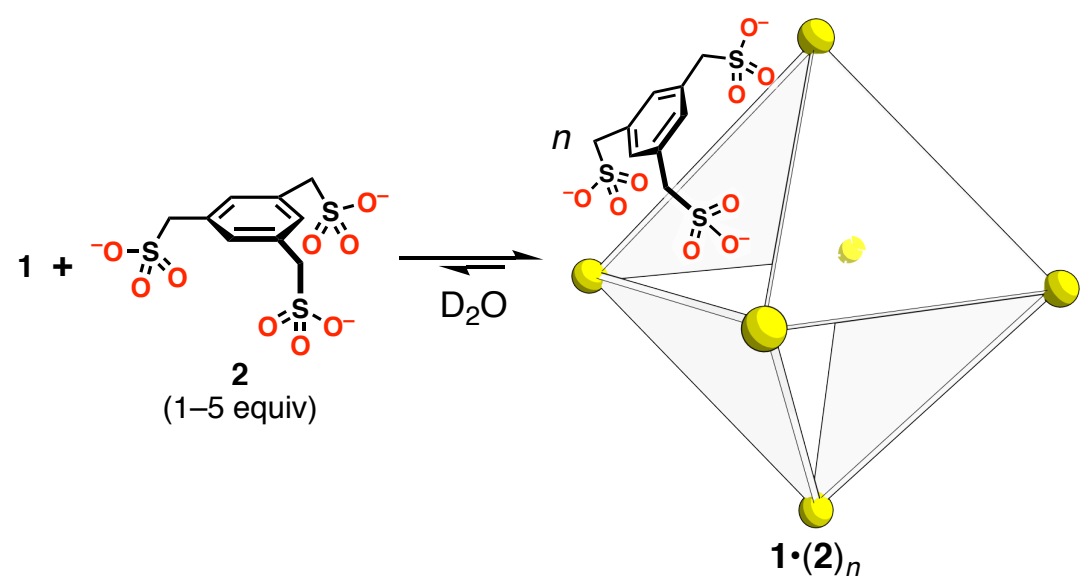

\section{A typical procedure}

Tripodal anion $2\left(0.60 \mathrm{mg}, 1.4 \mu \mathrm{mol}, 1.1\right.$ equiv) was added to a $\mathrm{D}_{2} \mathrm{O}$ solution of cage $\mathbf{1}(1.67 \mathrm{mM}, 0.75 \mathrm{~mL}$, 1 equiv) and stirred at room temperature for $1 \mathrm{~h}$. Then ${ }^{1} \mathrm{H}$ NMR spectrum of the solution was measured. As for the 1:5 mixture of $\mathbf{1}$ and $\mathbf{2}$, the $\mathrm{D}_{2} \mathrm{O}$ solution of cage $\mathbf{1}$ was diluted to $1.25 \mathrm{mM}$ to avoid the precipitation.

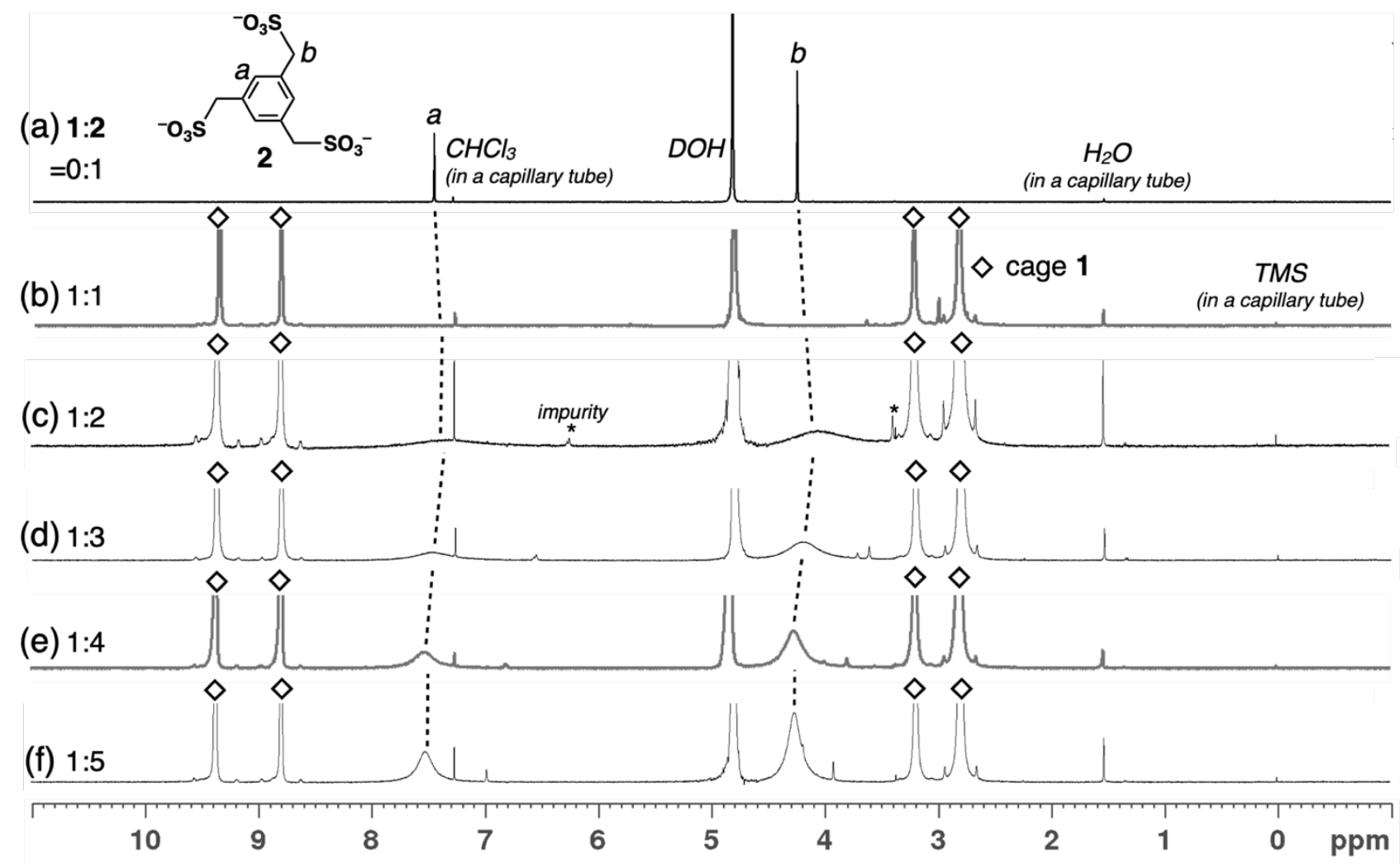

Figure S1. ${ }^{1} \mathrm{H}$ NMR spectra $\left(500 \mathrm{MHz}, \mathrm{D}_{2} \mathrm{O}, 300 \mathrm{~K}\right)$ of (a) anion 2 and (b)-(f) 1:n mixture of 1 and 2. 


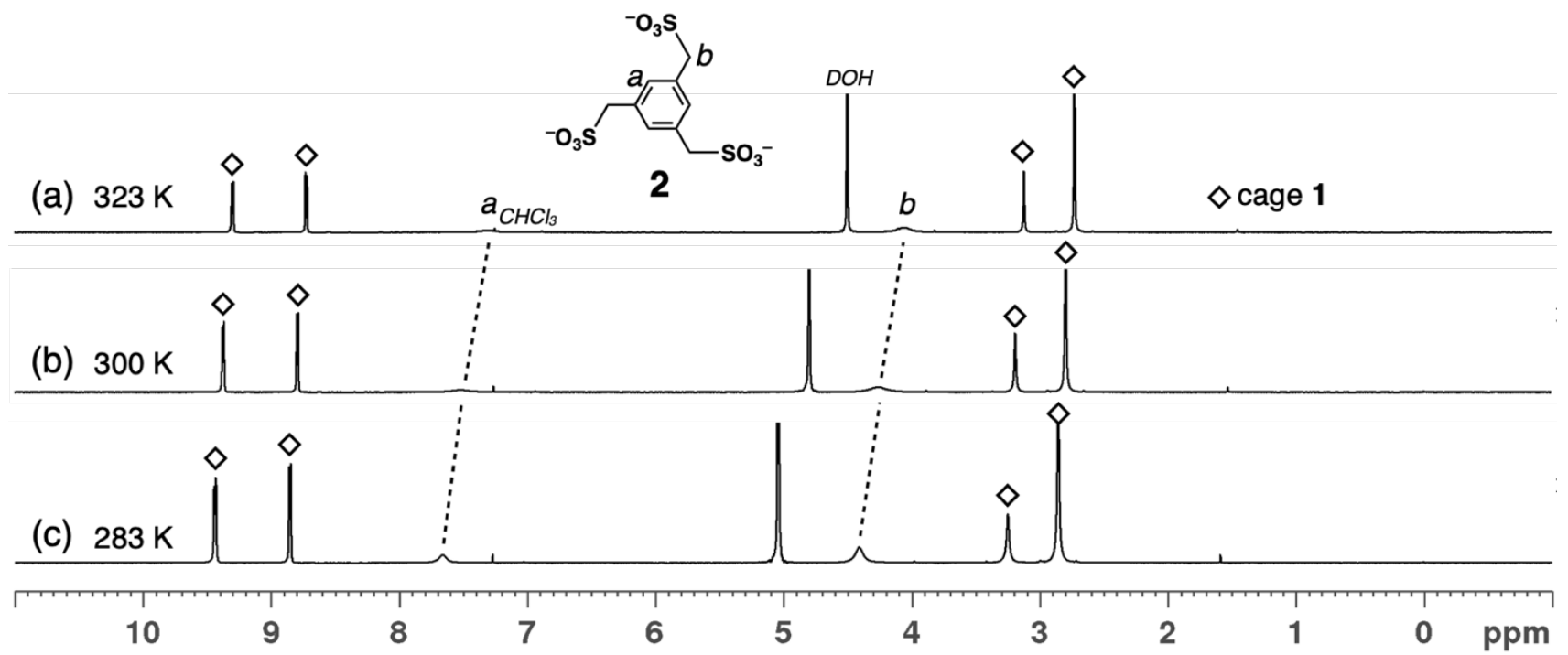

Figure S2. ${ }^{1} \mathrm{H}$ NMR spectra $\left(500 \mathrm{MHz}, \mathrm{D}_{2} \mathrm{O}\right)$ of $1: 4$ mixture of 1 and 2 at (a) $323 \mathrm{~K}$, (b) $300 \mathrm{~K}$, and (c) $283 \mathrm{~K}$.
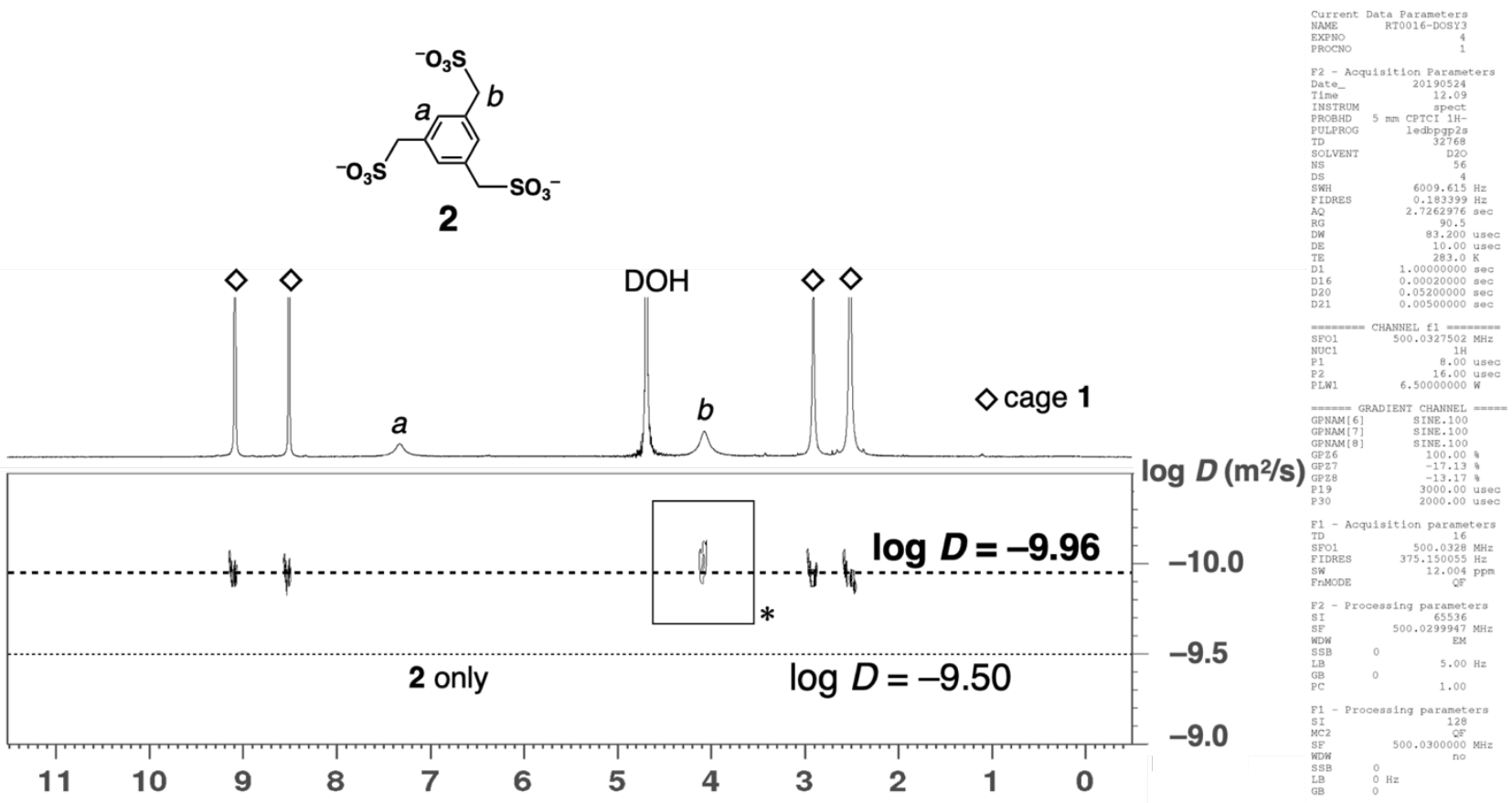

Figure S3. ${ }^{1} \mathrm{H}$ DOSY NMR spectrum $\left(500 \mathrm{MHz}, \mathrm{D}_{2} \mathrm{O}, 283 \mathrm{~K}\right)$ of $1: 4$ mixture of $\mathbf{1}$ and $\mathbf{2}$. The signal of anion 2 denoted by an asterisk is shown in the one-tenth threshold level (diffusion time: $52 \mathrm{~ms}$, length of diffusion gradient: $2 \mathrm{~ms}$, number of increments: 16 , number of scans: 56 , processing method: exponential). 


\section{X-ray crystallographic analyses of $1 \cdot 2$}

\section{Procedure for crystallization}

The reaction mixture of $\mathbf{1 . 2}$ was stood at $50{ }^{\circ} \mathrm{C}$ and the water solvent was allowed to evaporate. After two weeks, a single crystal suitable for X-ray diffraction analysis was obtained.

\section{Crystal data for $1 \cdot 2$}

\section{Table S1. Crystal data and structure refinement for $\mathbf{1 \cdot 2}$}

Identification code

CCDC number

Empirical formula

Formula weight

Temperature

Wavelength

Crystal system

Space group

Unit cell dimensions

Volume

Z

Density (calculated)

Absorption coefficient

$F(000)$

Crystal size

Theta range for data collection

Index ranges

Reflections collected

Independent reflections

Completeness to theta $=25.242^{\circ}$

Refinement method

Data / restraints / parameters

Goodness-of-fit on $F^{2}$

Final $R$ indices [I $>2 \operatorname{sigma(I)]~}$

$R$ indices (all data)

Absolute structure parameter

Largest diff. peak and hole ima2_a_sq

2022050

$\mathrm{C}_{117} \mathrm{H}_{153} \mathrm{~N}_{38} \mathrm{O}_{77.67} \mathrm{Pd}_{6} \mathrm{~S}_{3}$

4069.01

90(2) K

$0.71073 \AA$

Orthorhombic

Ima2

$a=32.464(3) \AA$

$\alpha=90^{\circ}$

$b=40.003(4) \AA$

$\beta=90^{\circ}$

$c=18.7989(16) \AA$

$\gamma=90^{\circ}$

24413(4) $\AA^{3}$

4

$1.107 \mathrm{Mg} / \mathrm{m}^{3}$

$0.532 \mathrm{~mm}^{-1}$

8265

$0.17 \times 0.13 \times 0.07 \mathrm{~mm}^{3}$

1.197 to $25.443^{\circ}$

$-39 \leqq h \leqq 39,-48 \leqq k \leqq 48,-22 \leqq l \leqq 22$

123443

$22972[R($ int $)=0.0868]$

$100.0 \%$

Full-matrix least-squares on $F^{2}$

22972 / 470 / 1244

1.069

$R_{1}=0.0822, w R_{2}=0.2189$

$R_{1}=0.1313, w R_{2}=0.2606$

$0.25(6)$

0.864 and $-0.627 \mathrm{e} \cdot \AA^{-3}$ 


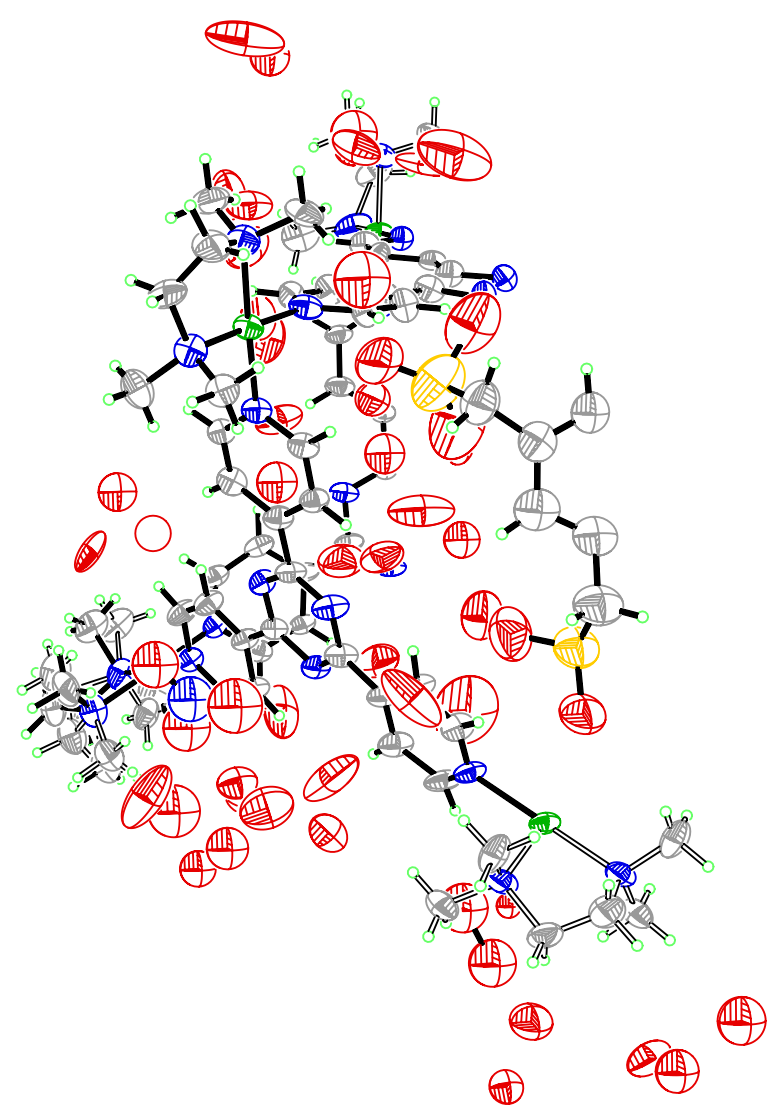

Figure S4. An ORTEP drawing (refinement structure, 30\% probability ellipsoids) of $\mathbf{1} \cdot \mathbf{2}$. 


\section{Inclusion of cationic guest 3 in cage 1 with the help of anion 2}

\section{Preparation of 1-adamantylammonium nitrate (3)}

1-Adamantylamine $(0.102 \mathrm{~g}, 0.672 \mathrm{mmol})$ was suspended in $\mathrm{H}_{2} \mathrm{O}$ and neutralized by $1 \mathrm{M} \mathrm{HNO}_{3}$. After filtration, the filtrate was concentrated under reduced pressure and dried in vacuo. 1-Adamantylammonium nitrate (3) was obtained as a white powder $(0.128 \mathrm{~g}, 0.599 \mathrm{mmol}, 89 \%)$.

\section{Inclusion experiments in the presence and absence of anion 2}
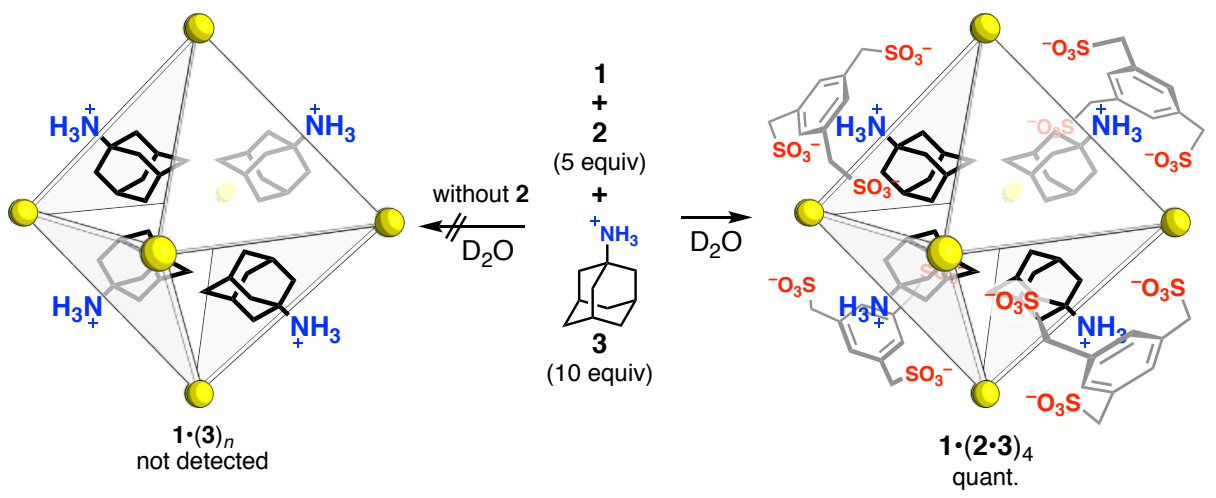

In the absence of anion 2

To a $\mathrm{D}_{2} \mathrm{O}$ solution of cage $\mathbf{1}(0.50 \mathrm{mM}, 2.0 \mathrm{~mL}, 1$ equiv) was added cationic guest 3 ( $2.15 \mathrm{mg}, 10.0 \mu \mathrm{mol}, 10$ equiv). After stirred at room temperature for $1 \mathrm{~h}$, the ${ }^{1} \mathrm{H}$ NMR spectrum of the reaction mixture was measured. In the presence of anion 2

To a $\mathrm{D}_{2} \mathrm{O}$ solution of cage $1(0.50 \mathrm{mM}, 2.0 \mathrm{~mL}, 1$ equiv) were added tripodal anion 2 (2.19 mg, $5.14 \mu \mathrm{mol}$, 5.1 equiv) and cationic guest $3(2.13 \mathrm{mg}, 9.94 \mu \mathrm{mol}, 9.9$ equiv). After stirred at room temperature for $1 \mathrm{~h}$, the ${ }^{1} \mathrm{H}$ NMR spectrum of the reaction mixture was measured.

\section{Chemical shift changes of 3 after inclusion}

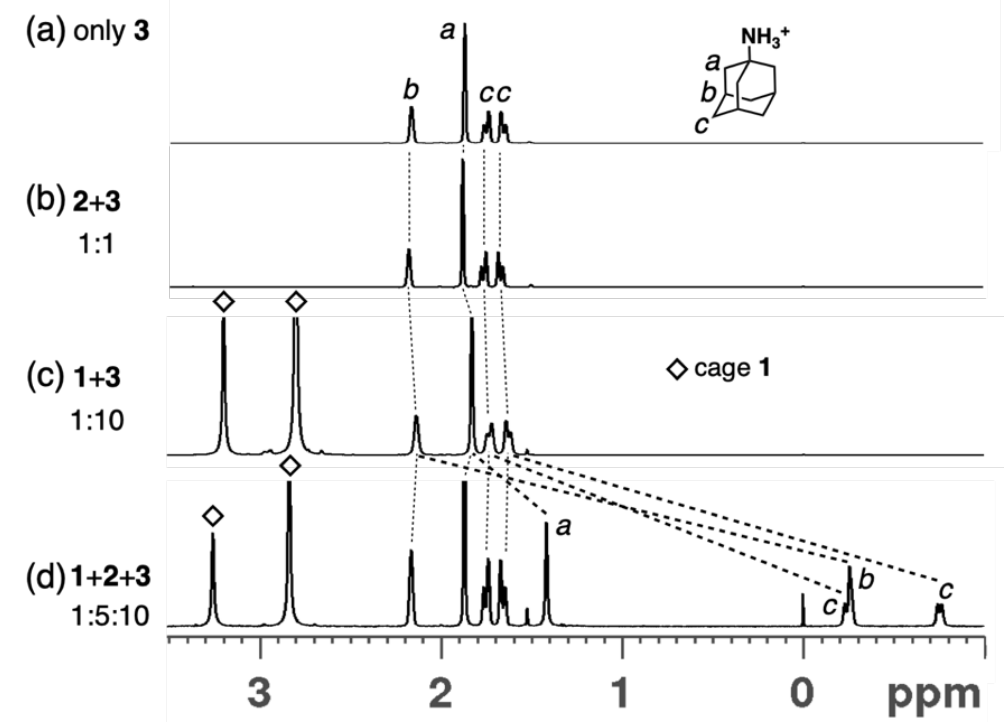

Figure S5. ${ }^{1} \mathrm{H}$ NMR spectra (500 MHz, $\mathrm{D}_{2} \mathrm{O}, 300 \mathrm{~K}$ ) of (a) guest 3, (b) 1:1 mixture of 2 and 3, (c) 1:10 mixture of $\mathbf{1}$ and $\mathbf{3}$, and (d) 1:5:10 mixture of $\mathbf{1}, \mathbf{2}$, and $\mathbf{3}$. 


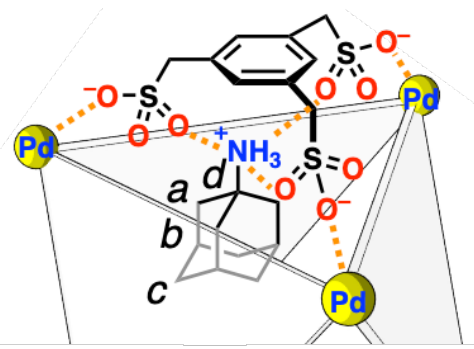

Physical data of 1:5:10 mixture of 1, 2, and 3: ${ }^{1} \mathrm{H}$ NMR $\left(500 \mathrm{MHz}, \mathrm{D}_{2} \mathrm{O}\right.$, $300 \mathrm{~K}): \delta=9.70\left(\mathrm{~d}, J=6.0 \mathrm{~Hz}, 24 \mathrm{H}, \mathbf{1}, \mathrm{Py} H_{\alpha}\right), 8.85(\mathrm{~d}, J=6.0 \mathrm{~Hz}, 24 \mathrm{H}, \mathbf{1}$, $\left.\mathrm{Py} H_{B}\right), 7.79(\mathrm{~s}, 3 \mathrm{H}, 2, \mathrm{ArH}), 4.59$ (s, 6H, 2, $\left.\mathrm{CH}_{2}\right), 3.27$ (s, 24H, 1, $\left.\mathrm{CH}_{2}\right), 2.85$ (s, 72H, 1, $\left.\mathrm{CH}_{3}\right), 2.17$ (br, 3H, $\left.\mathbf{3}_{\text {free }}, H_{\mathrm{b}}\right), 1.88\left(\mathrm{br}, 6 \mathrm{H}, \mathbf{3}_{\text {free }}, H_{\mathrm{a}}\right), 1.77-1.65$ (d, $J=12 \mathrm{~Hz}, 6 \mathrm{H}, \mathbf{3}_{\text {free, }} H_{\mathrm{c}}$ ), 1.42 (s, $6 \mathrm{H}, \mathbf{3}_{\text {included }} H_{\mathrm{a}}$ ), -0.23 (overlapped, $3 \mathrm{H}$, $\left.\mathbf{3}_{\text {included }}, H_{\mathrm{c}}\right),-0.26$ (s, 3H, $\left.\mathbf{3}_{\text {included }} H_{\mathrm{b}}\right),-0.75\left(\mathrm{~d}, J=10 \mathrm{~Hz}, 3 \mathrm{H}, \mathbf{3}_{\text {included }}, H_{\mathrm{c}}\right) ;{ }^{13} \mathrm{C} \mathrm{NMR}\left(125 \mathrm{MHz}, \mathrm{D}_{2} \mathrm{O}, 300 \mathrm{~K}\right)$ : $\delta=169.33(\mathbf{1}, \operatorname{Ar} C), 153.10(\mathbf{1}, \operatorname{ArC}), 144.76(\mathbf{1}, \operatorname{ArC}), 133.17(\mathbf{2}, \operatorname{ArC}), 133.13(\mathbf{2}, \operatorname{ArC}), 125.80(\mathbf{1}, \operatorname{ArC}), 63.20$ $\left(1, \mathrm{CH}_{2}\right), 57.40\left(2, \mathrm{CH}_{2}\right), 52.44\left(\mathbf{3}_{\text {free }}, C_{\mathrm{d}}\right), 50.85\left(3_{\text {included }}, C_{\mathrm{d}}\right), 50.72\left(1, \mathrm{CH}_{3}\right), 40.14\left(\mathbf{3}_{\text {free }}, C_{\mathrm{a}}\right), 38.78\left(\mathbf{3}_{\text {included, }}\right.$ $\left.C_{\mathrm{a}}\right), 34.98\left(\mathbf{3}_{\text {free }}, C_{\mathrm{c}}\right), 34.08\left(\mathbf{3}_{\text {included }}, C_{\mathrm{c}}\right), 28.91\left(\mathbf{3}_{\text {free }}, C_{\mathrm{b}}\right), 27.70\left(\mathbf{3}_{\text {included }}, C_{\mathrm{b}}\right)$.

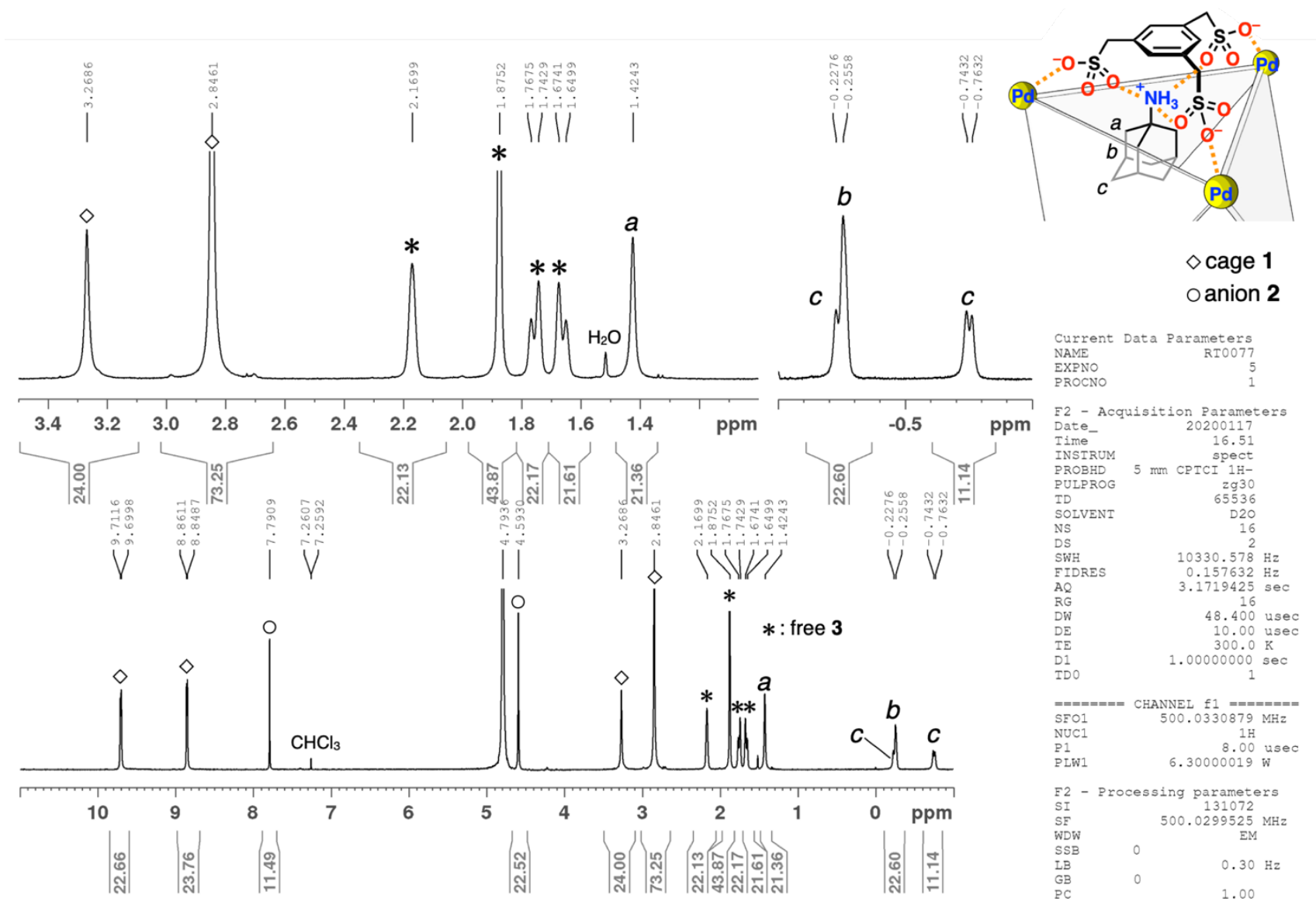

Figure S6. ${ }^{1} \mathrm{H}$ NMR spectrum $\left(500 \mathrm{MHz}, \mathrm{D}_{2} \mathrm{O}, 300 \mathrm{~K}\right)$ of 1:5:10 mixture of $\mathbf{1}, \mathbf{2}$, and $\mathbf{3}$. 

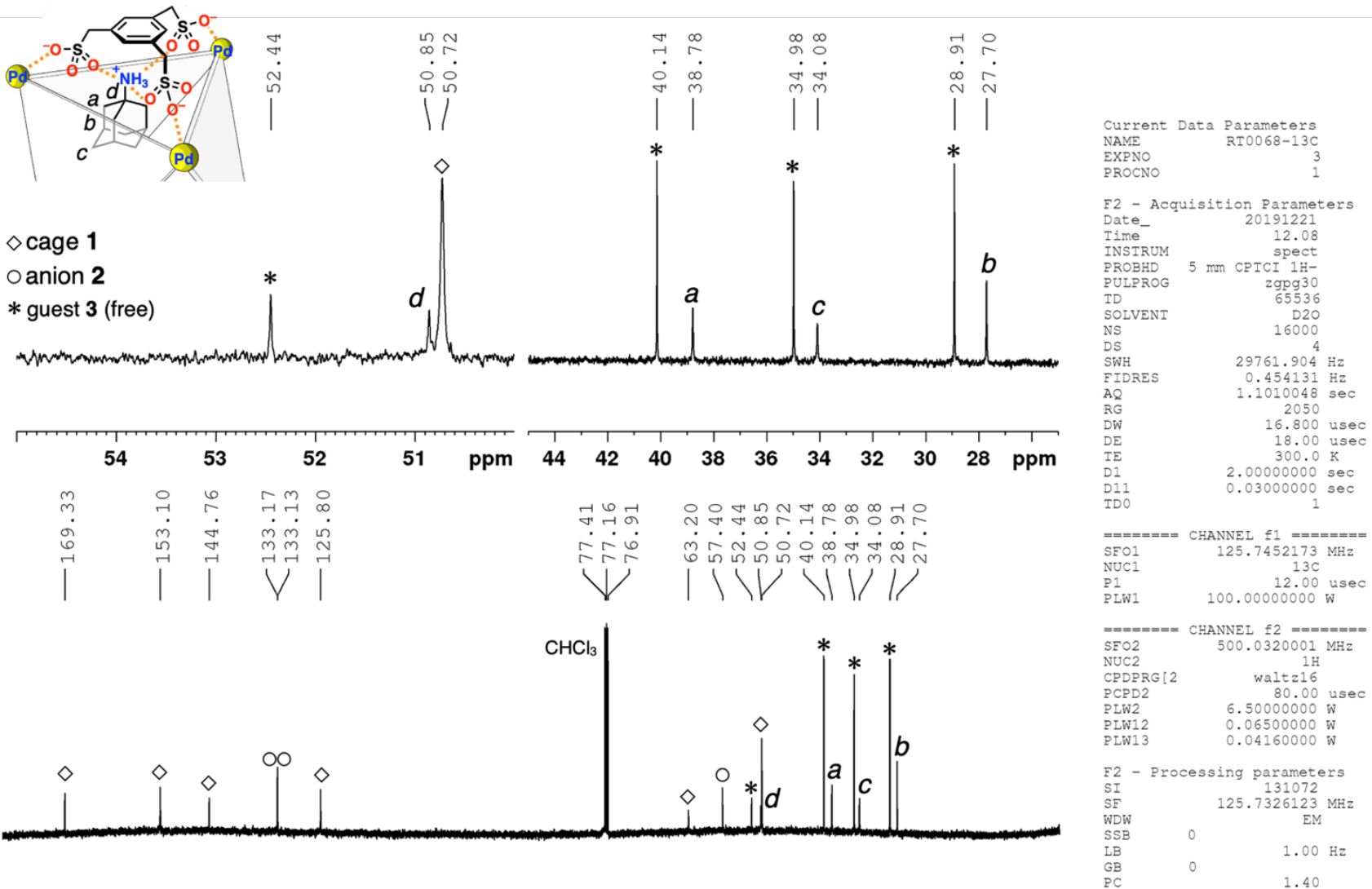

$\begin{array}{lllllllllllllllll}170 & 160 & 150 & 140 & 130 & 120 & 110 & 100 & 90 & 80 & 70 & 60 & 50 & 40 & 30 & 20 & \mathrm{ppm}\end{array}$

Figure S7. ${ }^{13} \mathrm{C}$ NMR spectrum $\left(125 \mathrm{MHz}, \mathrm{D}_{2} \mathrm{O}, 300 \mathrm{~K}\right)$ of 1:5:10 mixture of 1, 2, and $\mathbf{3}$.

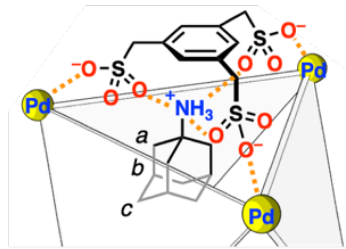

$\diamond$ cage 1

o anion 2
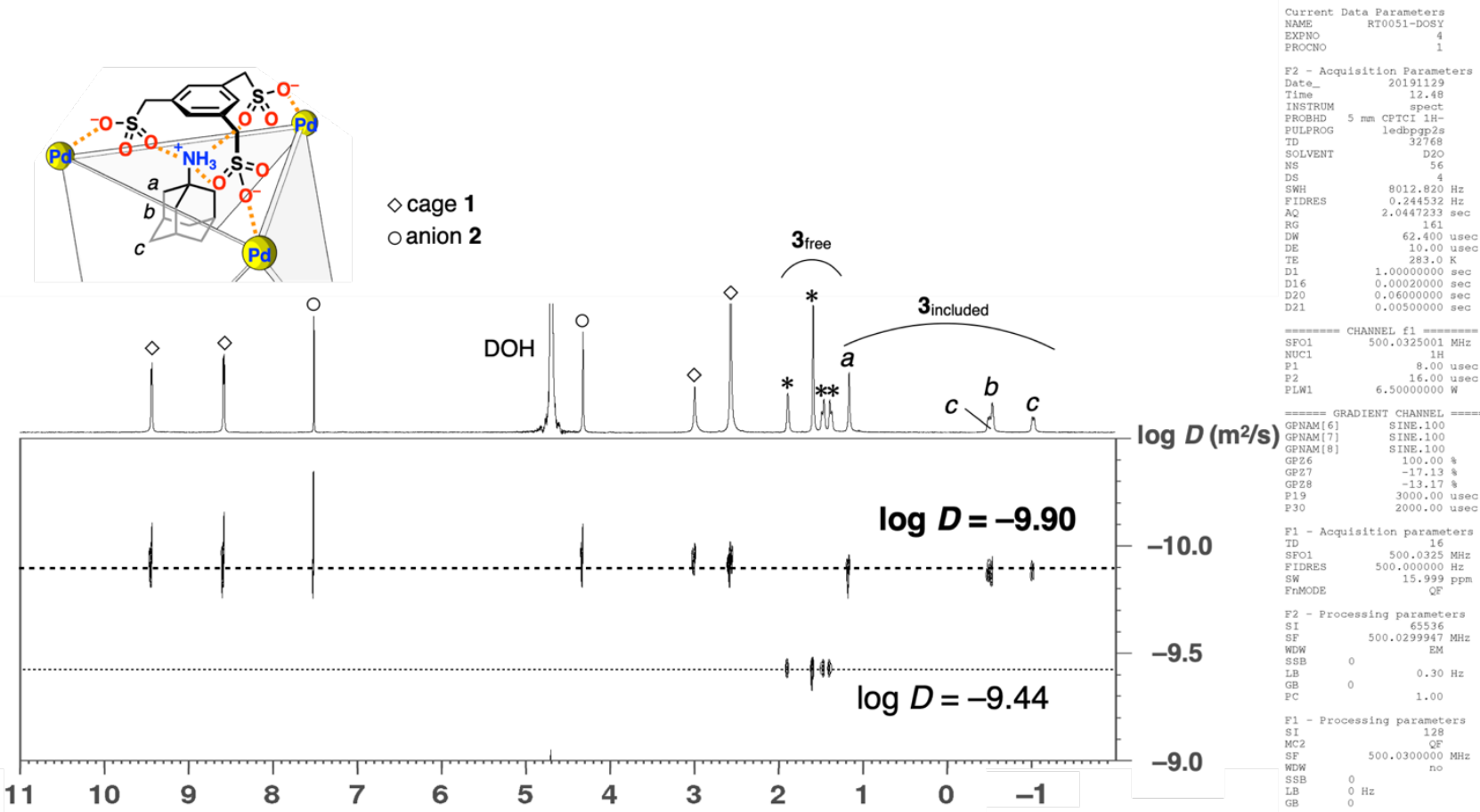

Figure S8. ${ }^{1} \mathrm{H}$ DOSY NMR spectrum $\left(500 \mathrm{MHz}, \mathrm{D}_{2} \mathrm{O}, 300 \mathrm{~K}\right.$ ) of 1:5:10 mixture of $\mathbf{1}, \mathbf{2}$, and $\mathbf{3}$ (diffusion time: $60 \mathrm{~ms}$, length of diffusion gradient: $2 \mathrm{~ms}$, number of increments: 16, number of scans: 56, processing method: exponential). 


\section{Comparison with different amounts of trianion 2}

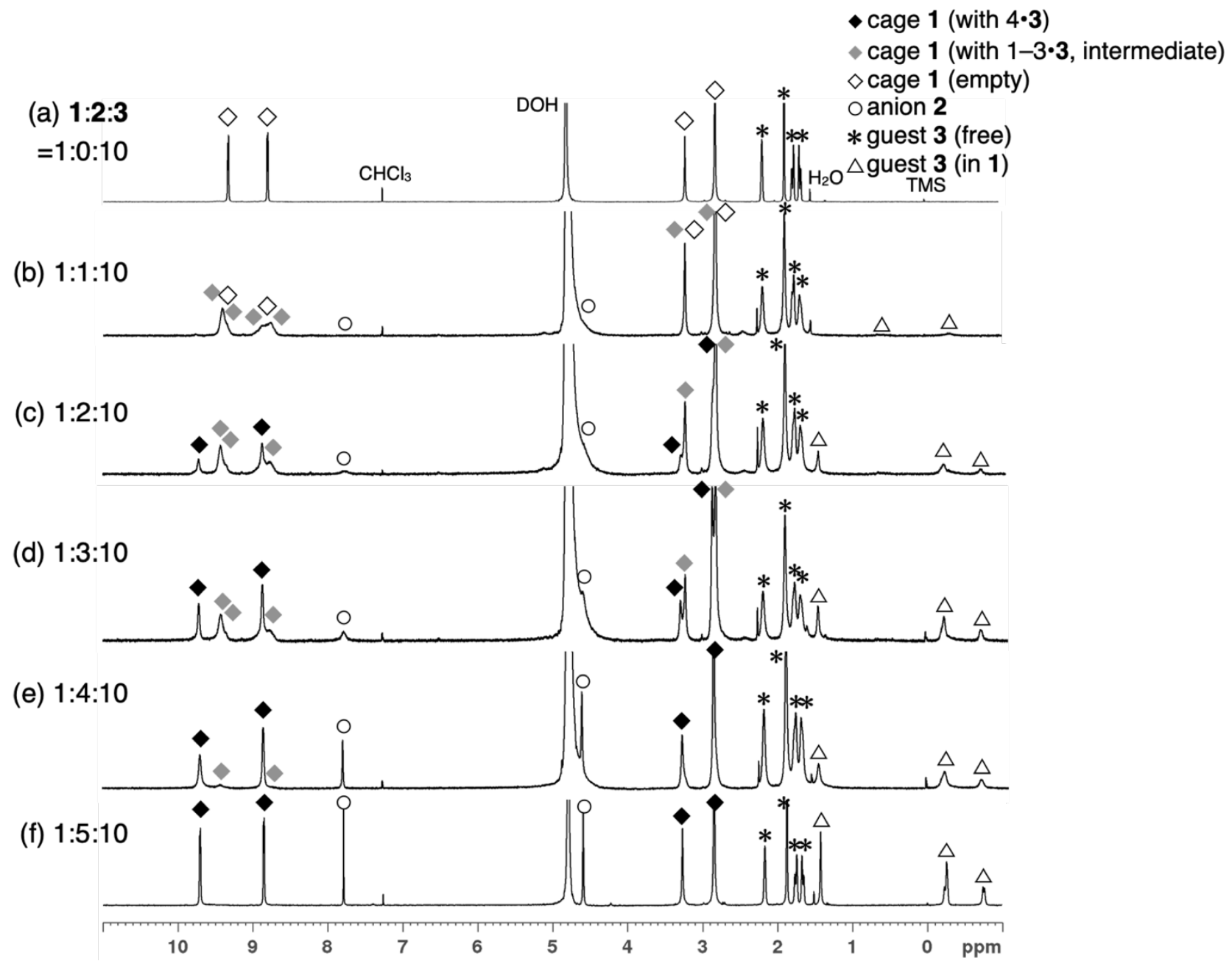

Figure S9. ${ }^{1} \mathrm{H}$ NMR spectra $\left(500 \mathrm{MHz}, \mathrm{D}_{2} \mathrm{O}, 300 \mathrm{~K}\right)$ of mixture of $\mathbf{1}, \mathbf{2}$, and 3. 


\section{X-ray crystallographic analyses of $1 \cdot(2 \cdot 3)_{4}$}

1:5:10 mixture of $\mathbf{1}, \mathbf{2}$, and $\mathbf{3}$ (chloride salt) was stood at $50^{\circ} \mathrm{C}$ and the water solvent was allowed to evaporate. After two weeks, a single crystal suitable for X-ray diffraction analysis was obtained.

\section{Crystal data for $1 \cdot(2 \cdot 3)_{4}$}

Table S2. Crystal data and structure refinement for $1 \cdot(2 \cdot 3)_{4}$

Identification conde

CCDC number

Empirical formula

Formula weight

Temperature

Wavelength

Crystal system

Space group

Unit cell dimensions

Volume

Z

Density (calculated)

Absorption coefficient

$F(000)$

Crystal size

Theta range for data collection

Index ranges

Reflections collected

Independent reflections

Completeness to theta $=21.396^{\circ}$

Refinement method

Data / restraints / parameters

Goodness-of-fit on $F^{2}$

Final $R$ indices [I $>2 \operatorname{sigma(I)]~}$

$R$ indices (all data)

Largest diff. peak and hole p-1

2022051

$\mathrm{C}_{193} \mathrm{H}_{260} \mathrm{~N}_{40} \mathrm{O}_{72.89} \mathrm{Pd}_{6} \mathrm{~S}_{15}$

5425.97

100(2) K

$0.71073 \AA$

Triclinic

$P-1$

$a=18.67(3) \AA$

$\alpha=87.008(14)^{\circ}$

$b=21.20(3) \AA$

$\beta=89.552(15)^{\circ}$

$c=33.52(5) \AA$

$\gamma=71.508(15)^{\circ}$

\section{$12563(31) \AA^{3}$}

2

$1.434 \mathrm{Mg} / \mathrm{m}^{3}$

$0.632 \mathrm{~mm}^{-1}$

5594

$0.17 \times 0.05 \times 0.04 \mathrm{~mm}^{3}$

1.150 to $21.396^{\circ}$.

$-18 \leqq h \leqq 18,-21 \leqq k \leqq 21,-33 \leqq l \leqq 33$

78181

$27180[R($ int $)=0.2360]$

$95.5 \%$

Full-matrix least-squares on $F^{2}$

$27180 / 1160 / 3117$

1.037

$R_{1}=0.1129, w R_{2}=0.2997$

$R_{1}=0.2731, w R_{2}=0.3928$

1.097 and $-0.913 \mathrm{e} \cdot \AA^{-3}$ 
(a)

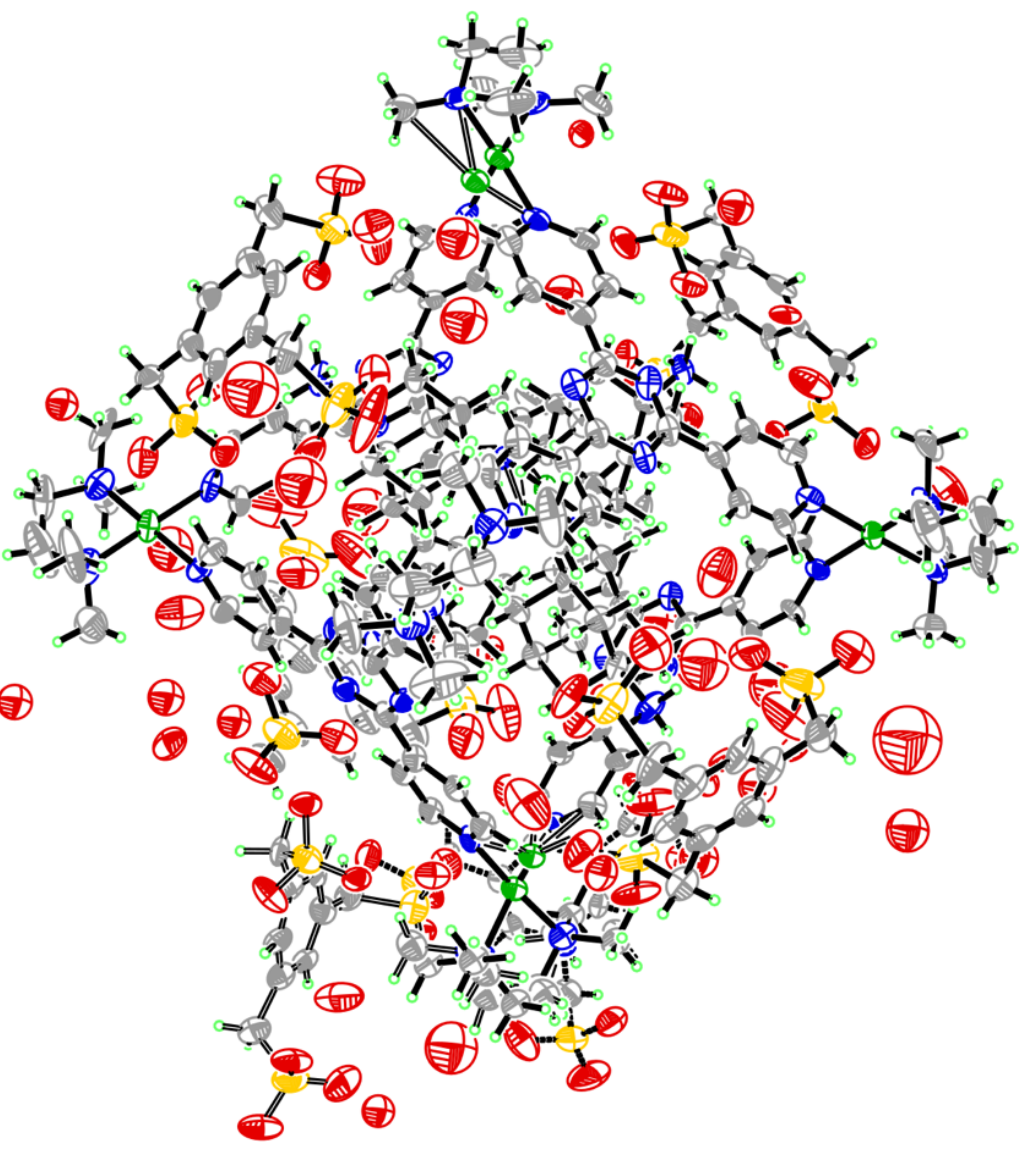

(b)

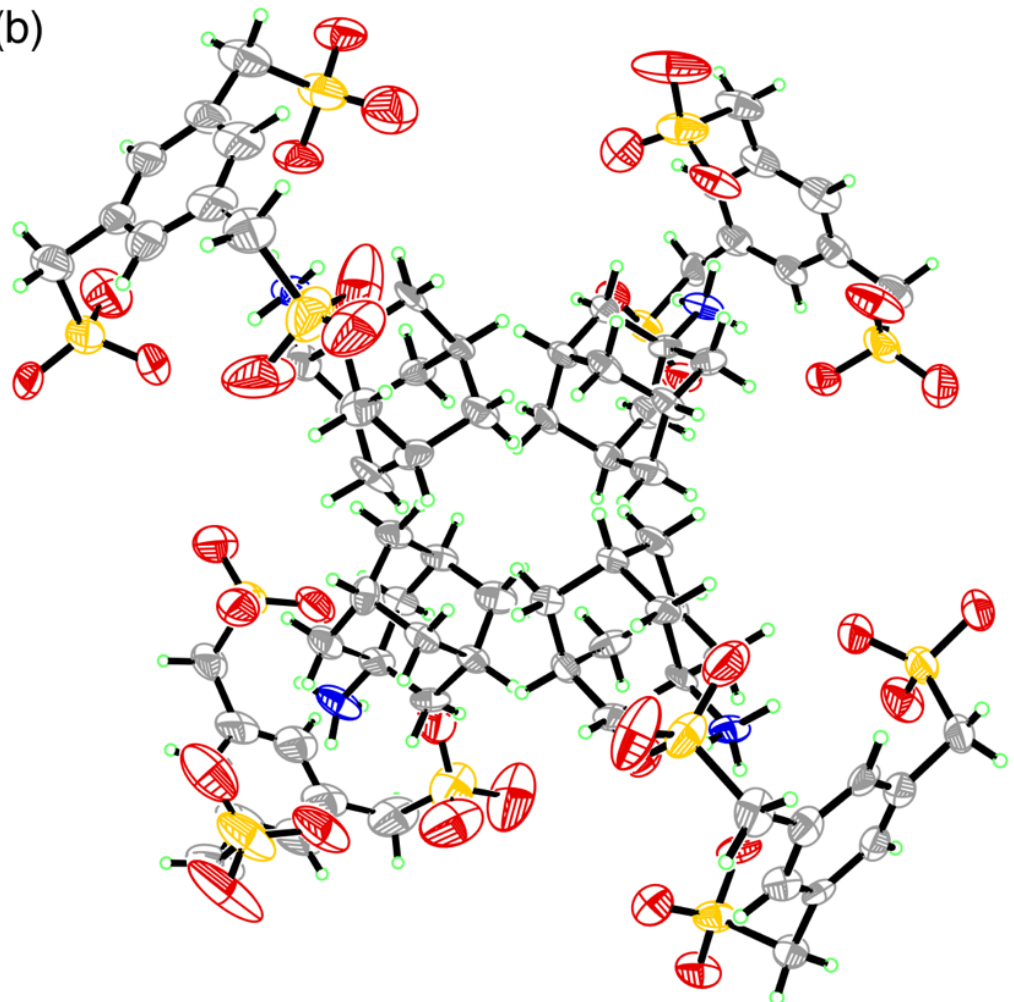

Figure S10. ORTEP drawings (30\% probability ellipsoids) of (a) the refinement structure and (b) the guests ( 2 and 3) in $\mathbf{1} \cdot(2 \cdot 3)_{4}$. 


\section{Inclusion of cationic substrates $4 a-c$ in cage 1 with the help of anion 2}

\section{General procedure for preparation of cationic substrates}

1, $\omega$-Alkanediamine $(0.196-0.285 \mathrm{mmol})$ was suspended in $\mathrm{H}_{2} \mathrm{O}$ and neutralized by $1 \mathrm{M} \mathrm{HNO}_{3}$. After filtration, the solvent water was removed in vacuo to give 1, $\omega$-alkanediammonium dinitrate as a white powder in quantitative yield.

\section{General procedure of inclusion experiments in the presence and absence of anion 2}
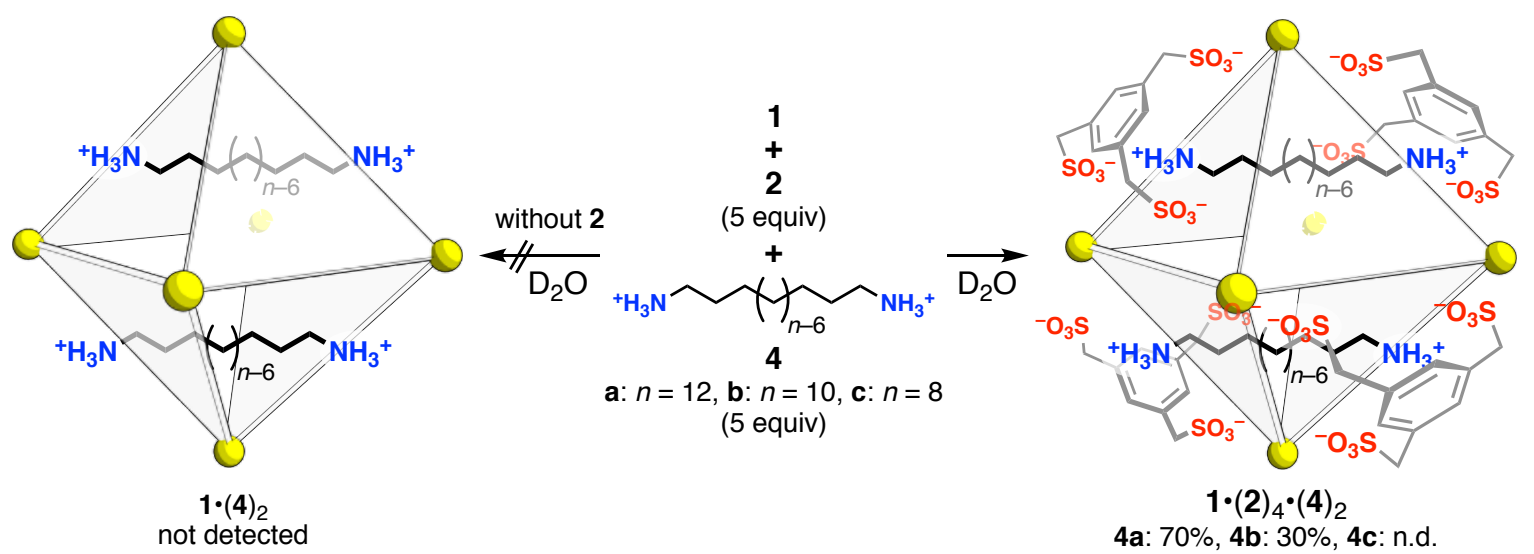

In the absence of anion 2

To a $\mathrm{D}_{2} \mathrm{O}$ solution of cage 1 ( $1.0 \mathrm{mM}, 1.0 \mathrm{~mL}, 1$ equiv) was added cationic guest 4 (1.51-1.58 mg, 4.84-5.59 $\mu$ mol, 4.8-5.6 equiv). After stirred at room temperature for $1 \mathrm{~h}$, the ${ }^{1} \mathrm{H}$ NMR spectrum of the reaction mixture was measured.

\section{In the presence of anion 2}

To a $\mathrm{D}_{2} \mathrm{O}$ solution of cage $1(1.0 \mathrm{mM}, 1.0 \mathrm{~mL}, 1$ equiv) were added tripodal anion 2 (2.14-2.16 mg, 5.02$5.07 \mu \mathrm{mol}, 5.0-5.1$ equiv) and cationic guest 4 (1.46-1.66 mg, 5.09-5.40 $\mu \mathrm{mol}, 4.7-5.5$ equiv). After stirred at room temperature for $1 \mathrm{~h}$, the ${ }^{1} \mathrm{H}$ NMR spectra of the reaction mixtures were measured. 


\section{Chemical shift changes of 4 after inclusion}

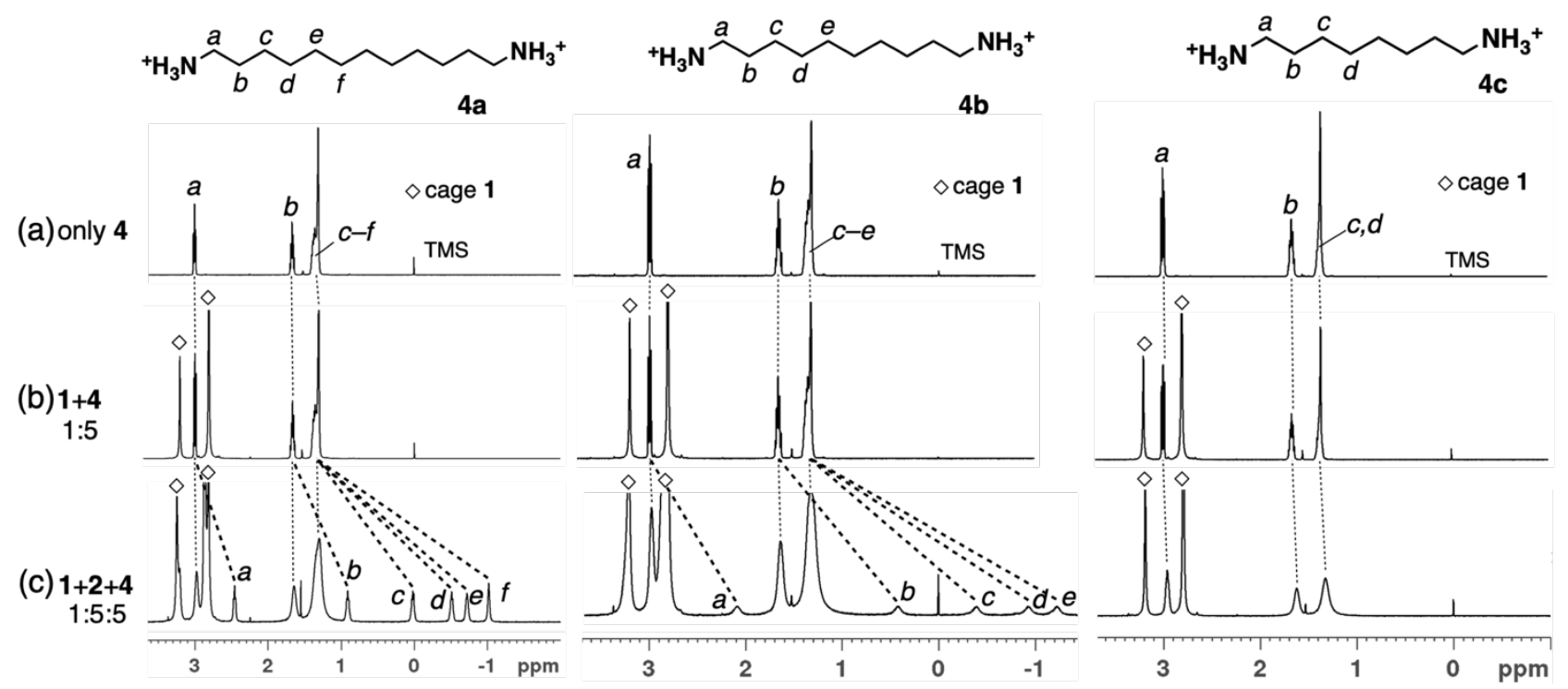

Figure S11. ${ }^{1} \mathrm{H}$ NMR spectra (500 MHz, $\mathrm{D}_{2} \mathrm{O}, 300 \mathrm{~K}$ ) of (a) guest 4, (b) 1:5 mixture of $\mathbf{1}$ and $\mathbf{4}$, and (c) 1:5:5 mixture of 1,2 , and 4 .

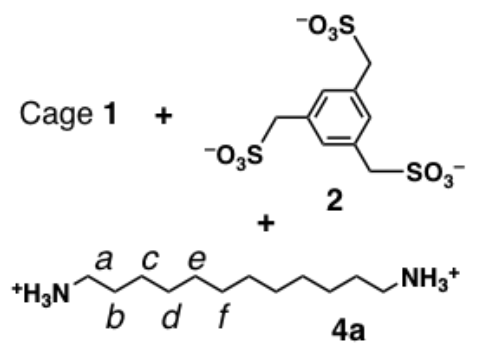

4a

Physical data of 1:5:5 mixture of 1, 2, and 4a: ${ }^{1} \mathrm{H}$ NMR $\left(500 \mathrm{MHz}, \mathrm{D}_{2} \mathrm{O}\right.$, 300K): $\delta=9.68$ (br, 8H, 1, Рy $\left.H_{\alpha}\right), 9.61$ (br, 8H, 1, Рy $H_{\alpha}$ ), 9.57 (br, 8H, 1, Рy $H_{\alpha}$ ), 9.41 (br, 24H, 1 (empty), Рy $H_{\alpha}$ ) 8.81 (br, 24H, 1, $\left.\mathrm{Py} H_{\beta}\right), 7.67$ (s, 3H, 2, $\mathrm{Ar} H$ ), 4.45 (s, 6H, 2, $\mathrm{CH}_{2}$ ), 3.24 (s, 24H, 1, $\mathrm{CH}_{2}$ ), 3.23 (s, 24H, 1 (empty), $\mathrm{CH}_{2}$ ), 2.97 (br, 4H, 4a $\left.\mathbf{a}_{\text {free }}, H_{\mathrm{a}}\right), 2.86$ (s, 72H, 1, $\left.\mathrm{CH}_{3}\right), 2.81$ (s, 72H, 1 (empty), $\left.\mathrm{CH}_{3}\right), 2.45$ (m, 4H, 4a $\left.\mathbf{a}_{\text {included }}, H_{\mathrm{a}}\right), 1.63\left(\mathrm{br}, 4 \mathrm{H}, \mathbf{4} \mathbf{a}_{\text {free }}, H_{\mathrm{b}}\right), 1.29$ (br, $\left.16 \mathrm{H}, \mathbf{4} \mathbf{a}_{\text {free }}, H_{\mathrm{c}-\mathrm{f}}\right), 0.90$

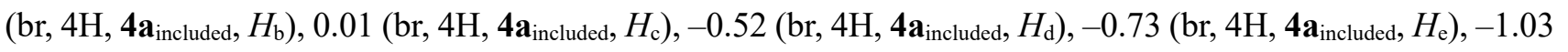
(br, 4H, 4a $\mathbf{a}_{\text {included }}, H_{\mathrm{f}}$ ). 

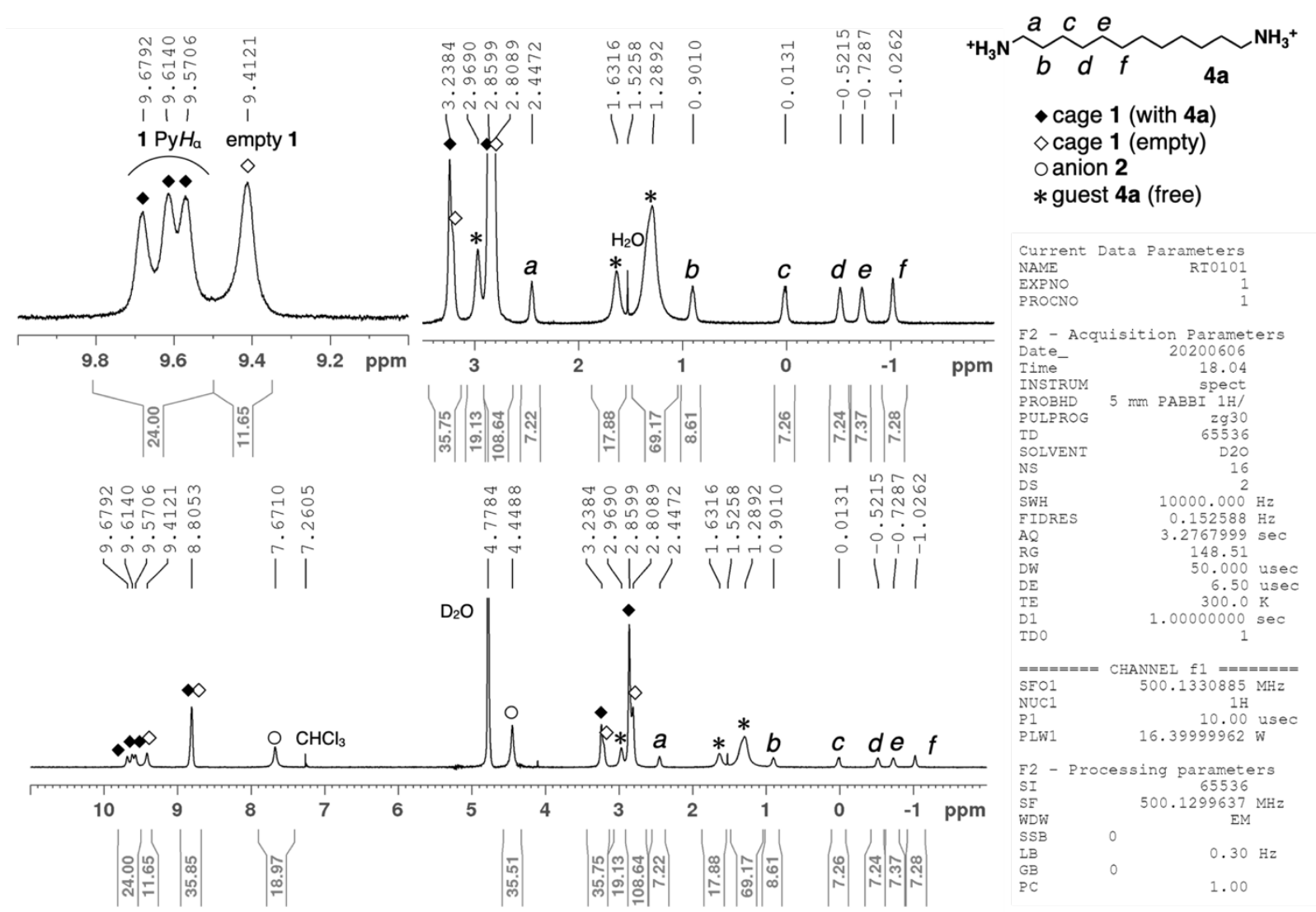

Figure S12. ${ }^{1} \mathrm{H}$ NMR spectrum $\left(500 \mathrm{MHz}, \mathrm{D}_{2} \mathrm{O}, 300 \mathrm{~K}\right)$ of 1:5:5 mixture of 1, 2, and $\mathbf{4 a}$.
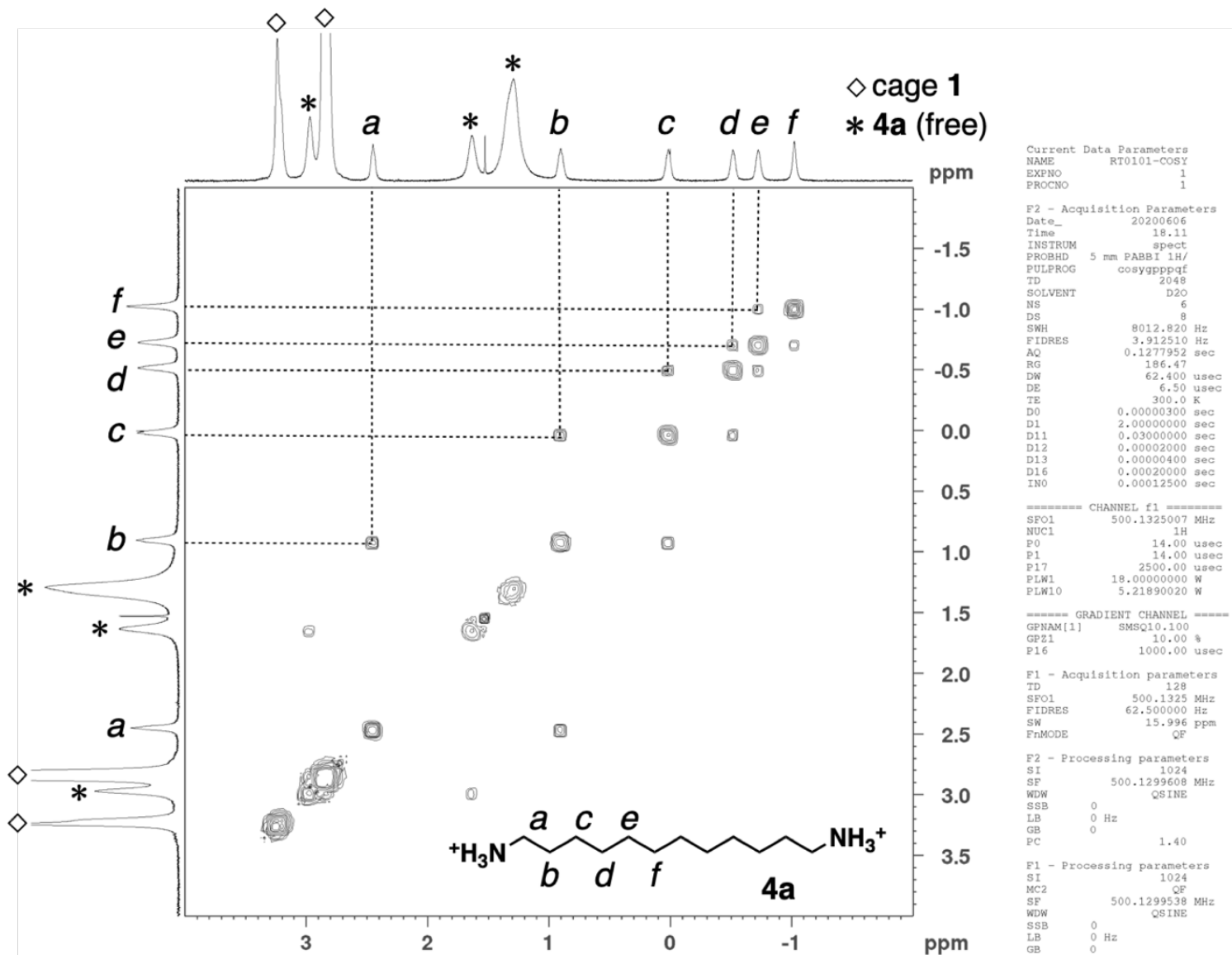

Figure S13. ${ }^{1} \mathrm{H}-{ }^{1} \mathrm{H}$ COSY NMR spectrum $\left(500 \mathrm{MHz}, \mathrm{D}_{2} \mathrm{O}, 300 \mathrm{~K}\right)$ of 1:5:5 mixture of $\mathbf{1}, \mathbf{2}$, and $\mathbf{4 a}$. 


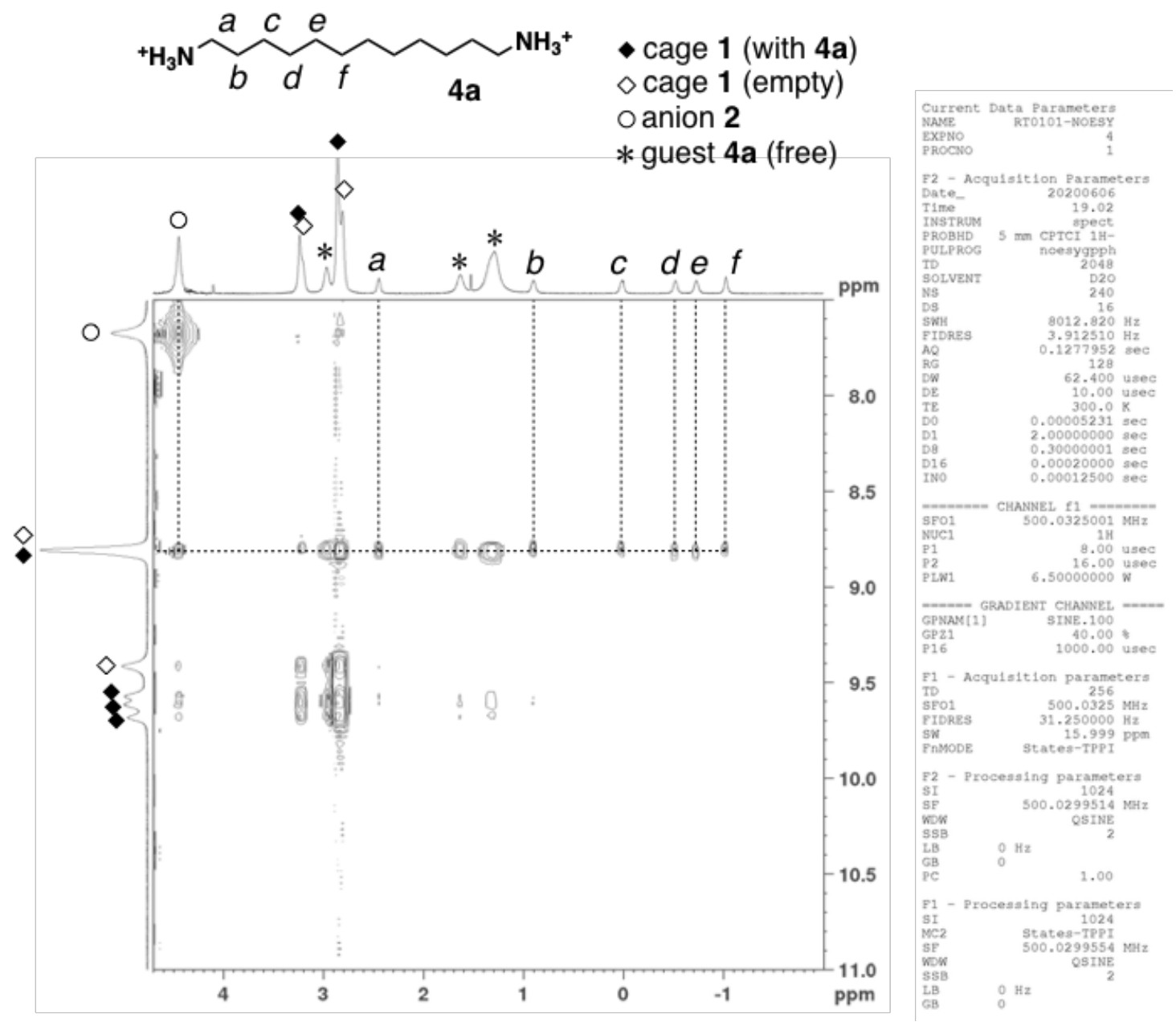

Figure S14. ${ }^{1} \mathrm{H}-{ }^{1} \mathrm{H}$ NOESY NMR spectrum $\left(500 \mathrm{MHz}, \mathrm{D}_{2} \mathrm{O}, 300 \mathrm{~K}\right)$ of 1:5:5 mixture of 1, 2, and 4a. 


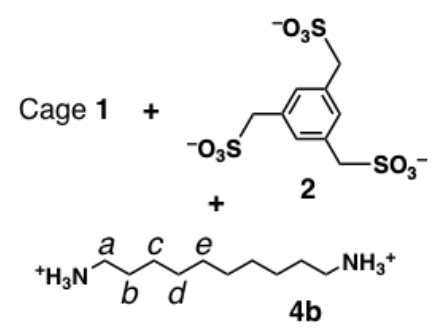

Physical data of 1:5:5 mixture of 1, 2, and 4b: ${ }^{1} \mathrm{H}$ NMR $\left(500 \mathrm{MHz}, \mathrm{D}_{2} \mathrm{O}, 300 \mathrm{~K}\right)$ : $\delta=9.64$ (br, 24H, 1, PyH $H_{\alpha}$ ), 9.40 (br, 24H, 1 (empty), $\mathrm{Py}_{\alpha}$ ) 8.79 (br, 24H, 1, $\left.\mathrm{Py}_{\beta}\right), 7.64$ (s, 3H, 2, ArH), 4.42 (s, 6H, 2, $\mathrm{CH}_{2}$ ), 3.21 (s, 24H, 1, CH $\mathrm{CH}_{2}, 2.98$ (br,

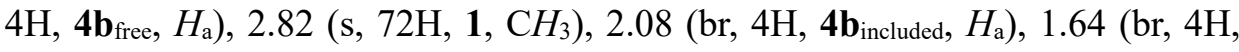
$\left.\mathbf{4} \mathbf{b}_{\text {free }}, H_{\mathrm{b}}\right), 1.31$ (br, $\left.12 \mathrm{H}, \mathbf{4} \mathbf{b}_{\text {free }}, H_{\mathrm{c}-\mathrm{e}}\right), 0.42$ (br, 4H, $\left.4 \mathbf{b}_{\text {included }}, H_{\mathrm{b}}\right),-0.40$ (br, $4 \mathrm{H}$, $\mathbf{4} \mathbf{b}_{\text {included }}, H_{\mathrm{c}}$ ), -0.94 (br, $\left.4 \mathrm{H}, \mathbf{4} \mathbf{b}_{\text {included }}, H_{\mathrm{d}}\right),-1.23$ (br, $4 \mathrm{H}, \mathbf{4} \mathbf{b}_{\text {included }}, H_{\mathrm{e}}$ ).
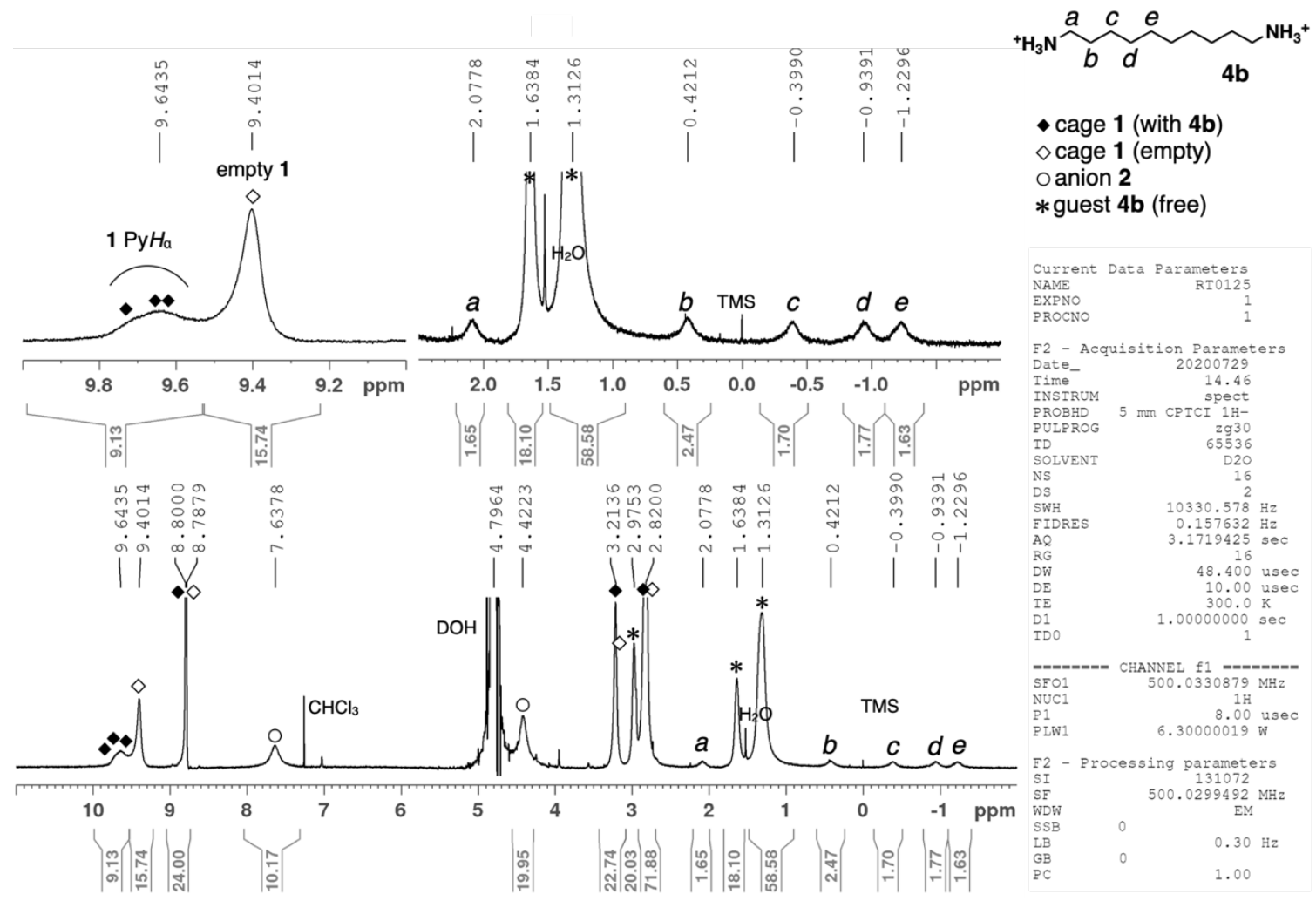

Figure S15. ${ }^{1} \mathrm{H}$ NMR spectrum $\left(500 \mathrm{MHz}, \mathrm{D}_{2} \mathrm{O}, 300 \mathrm{~K}\right)$ of 1:5:5 mixture of $\mathbf{1}, \mathbf{2}$, and $\mathbf{4 b}$.
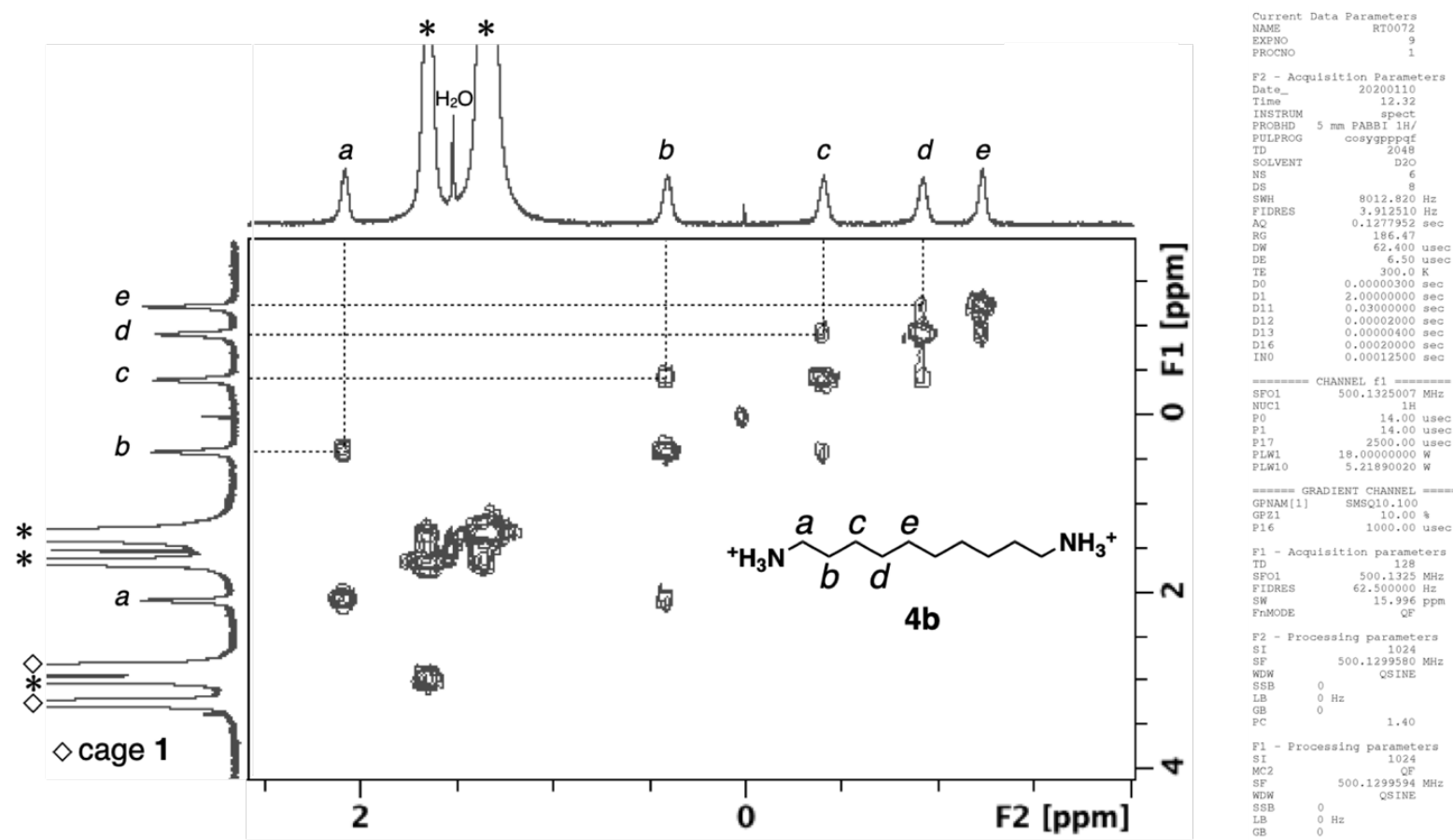

Figure S16. ${ }^{1} \mathrm{H}-{ }^{1} \mathrm{H}$ COSY NMR spectrum $\left(500 \mathrm{MHz}, \mathrm{D}_{2} \mathrm{O}, 300 \mathrm{~K}\right)$ of 1:5:5 mixture of $\mathbf{1}$, 2, and $\mathbf{4 b}$. 


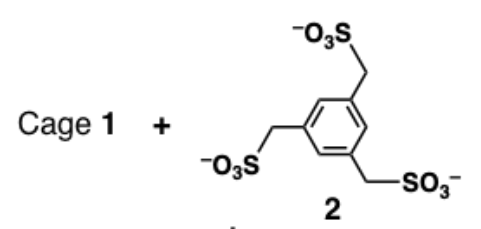

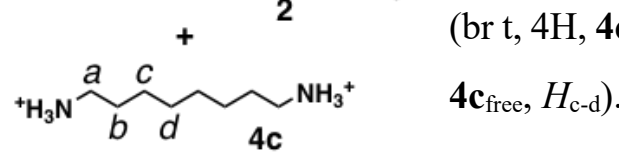
$300 \mathrm{~K}): \delta=9.39\left(\mathrm{~d}, J=6.2 \mathrm{~Hz}, 24 \mathrm{H}, \mathbf{1}, \mathrm{Py} H_{\alpha}\right), 8.78(\mathrm{~d}, J=6.2 \mathrm{~Hz}, 24 \mathrm{H}, \mathbf{1}$, $\left.\mathrm{Py} H_{\beta}\right), 7.50$ (br, 3H, 2, $\mathrm{ArH}$ ), 4.26 (br, 6H, 2, $\left.\mathrm{CH}_{2}\right), 3.19$ (s, 24H, 1, $\left.\mathrm{CH}_{2}\right), 2.96$

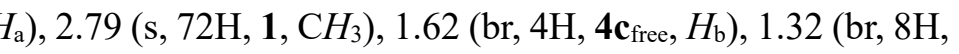
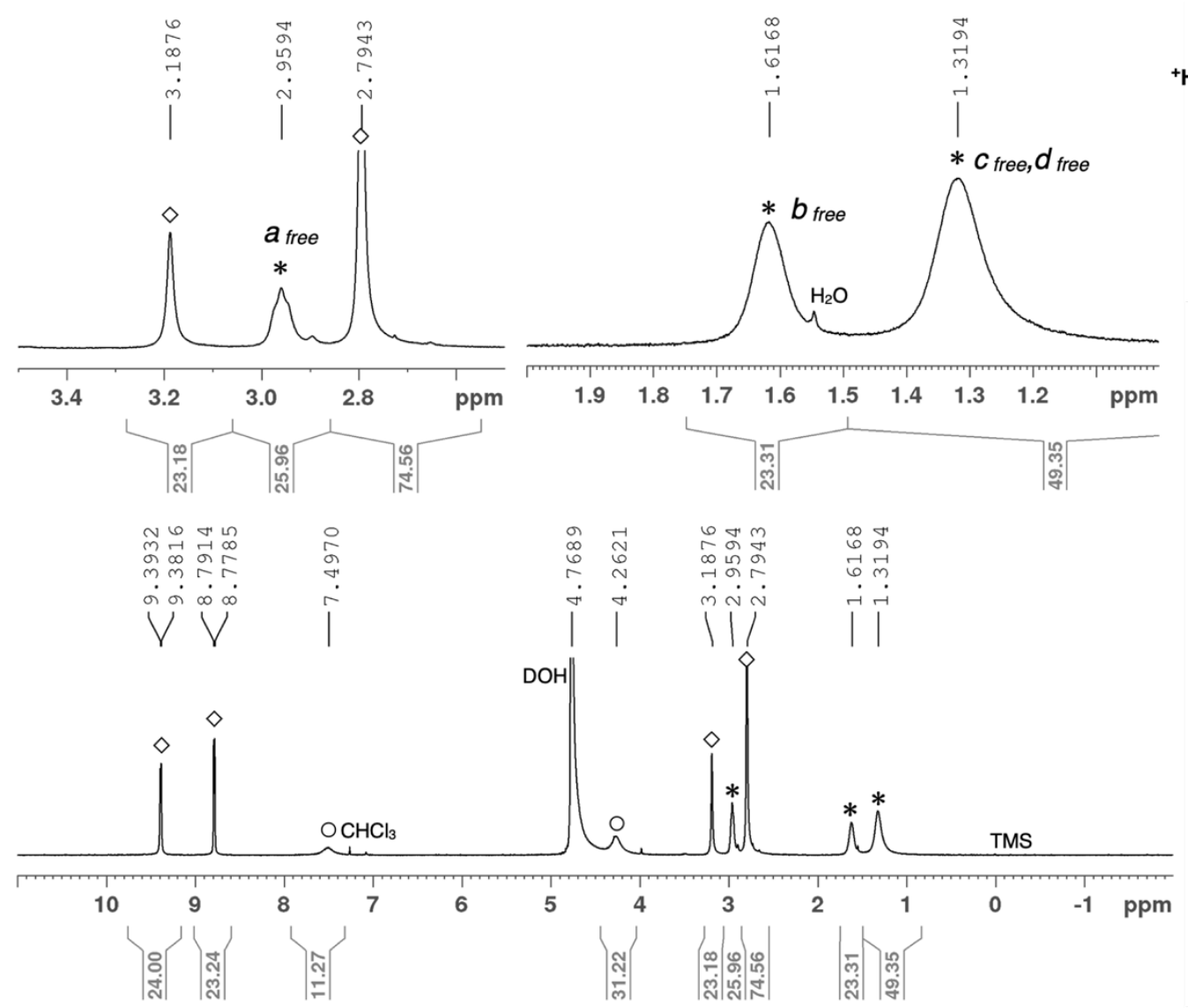

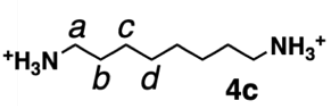

$\diamond$ cage 1 (empty) o anion 2 $*$ guest 4c (free)

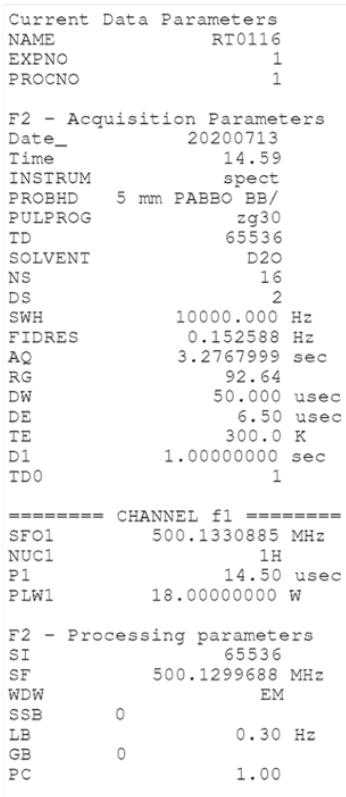

Figure S17. ${ }^{1} \mathrm{H}$ NMR spectrum $\left(500 \mathrm{MHz}, \mathrm{D}_{2} \mathrm{O}, 300 \mathrm{~K}\right)$ of 1:5:5 mixture of $\mathbf{1}$, 2, and $\mathbf{4 c}$. 


\section{Manipulative guest exchange by attaching of tripodal anion 2}
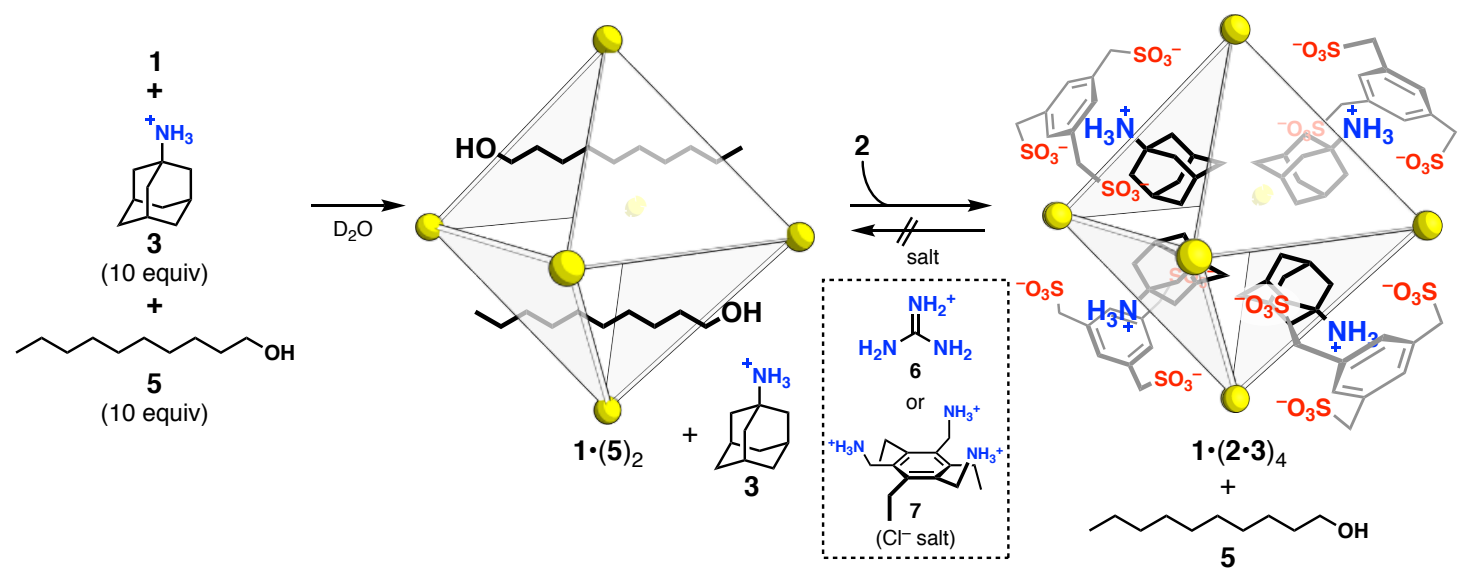

\section{Procedure of guest exchange}

To a $\mathrm{D}_{2} \mathrm{O}$ solution of cage $1(0.50 \mathrm{mM}, 2.0 \mathrm{~mL}, 1$ equiv) was added cationic guest 3 (2.12 mg, $9.89 \mu \mathrm{mol}$, 9.9 equiv) and neutral alcohol $5(1.9 \mu \mathrm{L}, 9.96 \mu \mathrm{mol}, 10$ equiv $)$. After stirred at room temperature for $1 \mathrm{~h}$, tripodal anion 2 (2.09 mg, $4.90 \mu \mathrm{mol}, 4.9$ equiv) was added to reaction mixture. After stirred at room temperature for 1 $\mathrm{h},{ }^{1} \mathrm{H}$ NMR spectrum of the reaction mixture was measured.

\section{Attempt to detach anion 2 from $1 \cdot(2 \cdot 3)_{4}$}

After guest exchange, to reaction mixture of $\mathbf{1 , 2 , 3}$, and $\mathbf{5}$ was added triangular cation $\mathbf{6}$ (6.18 $\mathrm{mg}, 64.7 \mu \mathrm{mol}$, 65 equiv). After stirred at room temperature for $1 \mathrm{~h},{ }^{1} \mathrm{H}$ NMR spectrum of the reaction mixture was measured. In other approach, equivalent of guest 5 was increased (10-times) and tripodal cation 7 (3.75 mg, $10.5 \mu \mathrm{mol}, 10$ equiv) was added. 


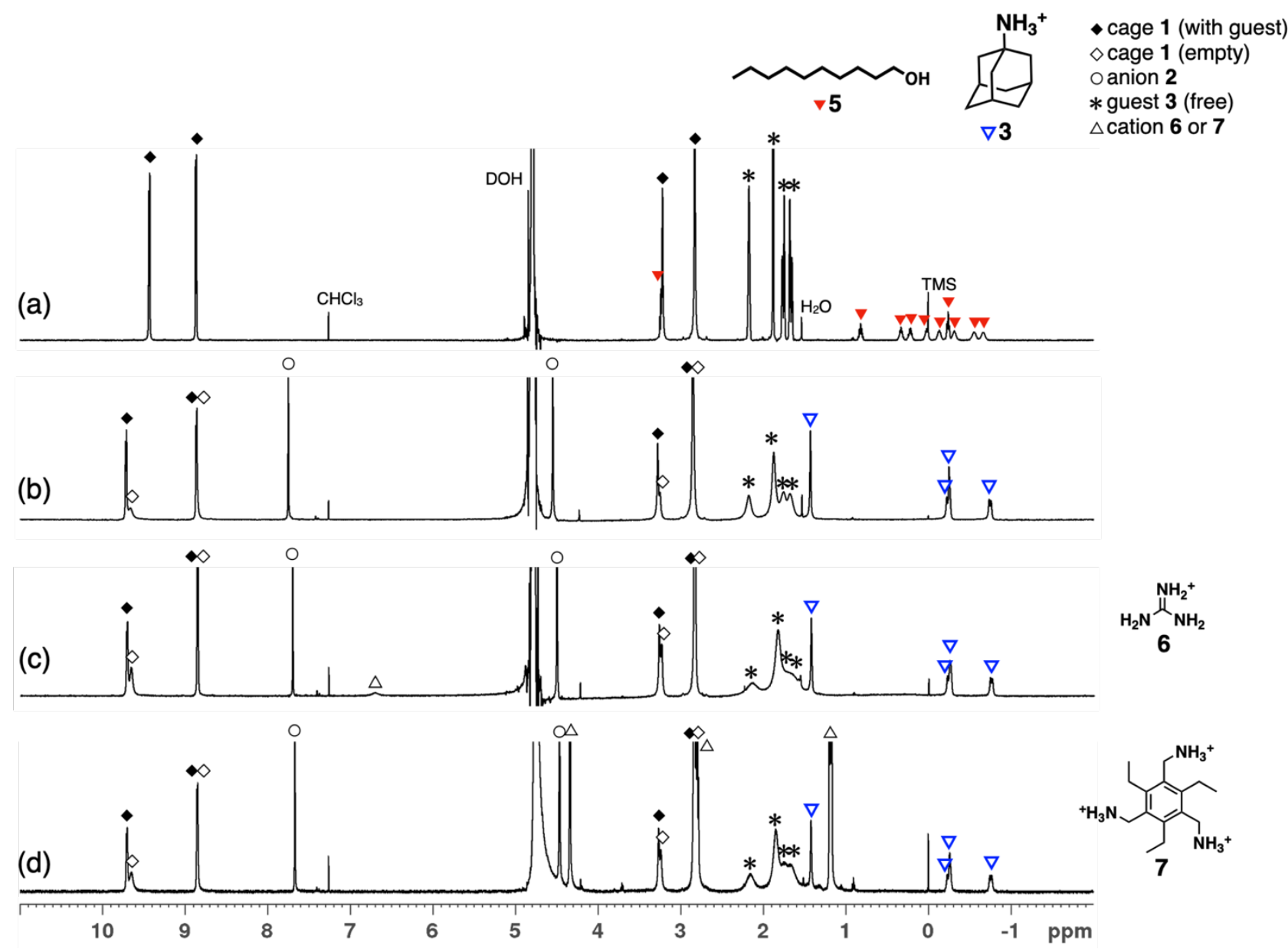

Figure S18. ${ }^{1} \mathrm{H}$ NMR spectra $\left(500 \mathrm{MHz}, \mathrm{D}_{2} \mathrm{O}, 300 \mathrm{~K}\right.$ ) of the mixtures of (a) 1 (1 equiv), $\mathbf{3}$ (10 equiv), and $\mathbf{5}$ (10 equiv), (b) 1, 2 (5 equiv), 3 (10 equiv), and 5 (10 equiv), (c) 1, 2 (5 equiv), $\mathbf{3}$ (10 equiv), 5 (10 equiv), and $\mathbf{6}$ (excess), and (d) 1, $\mathbf{2}$ (5 equiv), $\mathbf{3}$ (10 equiv), $\mathbf{5}$ (100 equiv), and $\mathbf{7}$ (excess).

\section{[References]}

1. Fujita, M.; Oguro, D.; Miyazawa, M.; Oka, H.; Yamaguchi, K.; Ogura, K. Self-Assembly of Ten Molecules into Nanometre-Sized Organic Host Frameworks. Nature 1995, 378, 496-471.

2. Dalrymple, S. A.; Parvez, M.; Shimizu, G. K. H. Intra- and Intermolecular Second-Sphere Coordination Chemistry: Formation of Capsules, Half-Capsules, and Extended Structures with Hexaaquo- and Hexaamminemetal Ions. Inorg. Chem. 2002, 41, 6986-6996.

3. Sheldrick, G. M. Crystal Structure Refinement with SHELXL. Acta Crystallogr. Sect. C Struct. Chem. 2015, 71, 3-8.

4. Hübschle, C. B.; Sheldrick, G. M.; Dittrich, B. ShelXle : A Qt Graphical User Interface for SHELXL. J. Appl. Crystallogr. 2011, 44, 1281-1284.

5. Spek, A. L. PLATON SQUEEZE: A Tool for the Calculation of the Disordered Solvent Contribution to the Calculated Structure Factors. Acta Crystallogr. Sect. C Struct. Chem. 2015, 71, 9-18. 